Spatial Demography 2013 1(1): 56-95

http://spatialdemography.org

OPEN ACCESS

via Creative Commons 3.0
SPATIAL DEMOGRAPHY

ISSN 2164-7070 (online)

\title{
RESEARCH
}

\section{Spatial Inequality in Wealth: A Bayesian Analysis of the Northeastern US in 1860 - Does Space Matter?}

\author{
Alice Bee Kasakoffa, Andrew B. Lawsonb, Purbasha \\ Dasguptab, Stephen Feethamc, Michael J. DuBoisa \\ aUniversity of South Carolina \\ bMedical University of South Carolina \\ cResearch Planning, Inc.
}

\begin{abstract}
Individual inequality is growing in America today and the subject is of great interest. But spatial inequality -"how and why spatial context contributes to inequality" (Labao et. al. 2007:3) -has just begun to be studied. If certain geographical areas are inherently richer due to accessibility, population size, or soils, for example, how much individual equality can a society hope to achieve? Furthermore, inequality due to spatial differences seems to endure over time (Labao and Hooks 2007:48; Peters 2012) and may be quite difficult to alter. This paper describes spatial inequality in wealth at the county level in the middle of the nineteenth century in the Northeastern US at a time when the US economy was growing rapidly and individual inequality was increasing. It applies Bayesian hierarchical spatial modeling in an attempt to understand the underlying causes of the differences in wealth between counties. The underlying spatial structure of inequality was rather different at this time: indeed, the urban agglomerations and industrial economy we know today were just coming into being. A unique feature of our work is the inclusion of a measure of soil quality that has not been used so far in either historical or contemporary investigations.
\end{abstract}

Keywords: Spatial inequality, 19th century Northeastern US, Bayesian spatial analysis, soil quality

\section{INTRODUCTION}

This research is part of a larger project to study the transmission of wealth within families in the US North using a genealogical sample of individuals descended from founders who had come to the US prior to 1650 when most of the ancestors of the population that later became known as "Yankees" had come. That study relies upon information on the wealth of individuals, their real and personal property, which can be found in the censuses of 1850,1860 and 1870 . For the contemporary United States census data and other surveys make it possible to study inequality directly within counties and other spatial units, but this type of data is not readily

${ }^{a}$ University of South Carolina

Corresponding Author: Alice Bee Kasakoff, University of South Carolina, Department of Geography, 709 Bull Street, Columbia, SC 29208.

E-mail: Kasakoff@sc.edu 
available for the $19^{\text {th }}$ century. Therefore in this study we use information on different forms of capital at the county level in order to understand the larger forces at work. In addition to the county-average wealth of individuals, we study county level measures of wealth in two major sectors: the value of farm land per acre and the capital invested in manufacturing.

In our introductory section, we sketch the theoretical and historical background and introduce the specific questions we will address. In Part I we discuss the data and present a simple measure of spatial inequality for the three variables we later analyze in more detail. In Part II we discuss the methods and the variables in the analyses. Part III presents our spatial analyses. We conclude with a discussion of how what we have found might have affected inequality at the individual level at the time and point out that many of the features of the spatial system we describe continue within the region today.

\section{Part I: Background}

\section{A. Theory}

Kuznets proposed that economic growth resulted in an inverted $U$ shaped curve of inequality in individual incomes (1955). During the early stages of economic development, a country would experience rising inequality, which would first level off and then decline. The decline was due, in part, to the increasing dependence of income on education. When he wrote, data were not available for many countries, but he concluded that in the US the stage of increasing inequality lasted until 1890. Since his work, some have argued that economic inequality was increasing in the US during the $19^{\text {th }}$ century(Pope 2000; Steckel and Mohling 2001). But Williamson (1991; see also Williamson and Lindert 1980) concluded it had risen until the Civil War, which was followed by an "uneven" plateau which lasted until the 1920's. Margo agreed, arguing from the ratio of wages of educated to non-educated workers (2000:157). Thus in 1860, the date of our study, the US had either reached a peak of inequality or inequality was still increasing.

How important were the spatial differences that resulted from economic growth in creating inequality in individual incomes? Kuznets' explanation for the curve included industrialization and the increase in urban populations, both of which are spatial phenomena. But he did not include differences within the agricultural sector created by the new urban markets for agricultural products. Williamson and Lindert (1980) explained rising inequality chiefly by premiums paid for skills early in industrialization. They did not include the agricultural sector because inequality in both wealth and income rose between 1820 to 1860 just when more land became available for settlement (Williamson and Lindert 1980: 140141). Meyer (2003), by contrast, pointed out that industrialization in the Northeastern US was in fact dependent upon prior increases in productivity in agriculture which were clustered spatially and which created capital that could be invested in manufacturing and also released labor into that sector.

The population of the Northeastern US was largely rural in 1860: only $35 \%$ of the population lived in localities with more than 2500 inhabitants. Southern New England was more urban (52\%); the mid Atlantic (35\%) and northern New England (14\%) were less so (Meyer 2003: 5). A large percentage of wealth was in farms held by small holders who worked the farms largely using family labor. At this time, only farms located far from urban markets or transportation were not producing for the market. However, grain was produced outside the region, in the Middle West. Within the region, most farmers were producing specialized goods or dairy products.

There has been a great deal of debate about the contributions of railroads and canals to economic growth in the US at this time and whether the sizeable investments required to build them paid off. Railroads were available in the great majority of counties in 1860 but water transportation was not: two major waterways used for shipping, the Erie Canal and the Hudson/Champlain waterway, 
met in Albany, New York. Most scholars agree that the first wave of canal construction (between 1820 and 1836) when the Erie and Champlain canals were built, was economically successful, but later canals and earlier canals built in New England were not able to supplant wagon transport which was used to bring products to urban markets (Meyer 2003: 141, 154-55, Fishlow 2000:606). Thus the canals are a prime example of a spatial feature that must have resulted in inequality in wealth.

As for railroads, until 1860, Meyer felt they served largely the needs of passengers and high value freight, while bulky freight went by canal or wagon. Fishlow, on the other hand, felt the expansion of railroads did pay off. His calculations include the increases in land values due to transportation. And recently, Atack et.al. (2010) demonstrated that in the Middle West, railroads were responsible for bringing people to the region. In the Northeast, however, the people were already there when the railroads were built and their role was probably different. Eastern manufacturing and profits to large textile firms preceded the railroad and the railroad did not result in a great change in manufacturing profits, largely because transportation accounted for very little of the cost of manufactured goods (Fishlow 2000:619).

Today the relationship of income to inequality has changed. Inequality has begun to increase again in many industrialized countries despite increased economic growth and scholars have been investigating the role of spatial factors in this change. Studies of US counties from the 1970's to 2009 have called attention to the roles of deindustrialization and the growing importance of service sector jobs which have polarizing effects upon incomes (e.g. Peters 2012). Demographic changes in households and the entry of women into the labor force, education, urbanization and institutional factors (Moller, et. al. 2009) have also contributed to rising inequality. While these studies emphasize a uniform set of causes over the entire United States, a recent study of child poverty shows that processes producing child poverty differ in different parts of the United States (Curtis, et. al.
2012). The farm sector has all but vanished from these studies, but it is useful to look at an earlier period when it was quite important, not only because many of the spatial patterns we observe today had their roots in a period when farming was more important, but also because the process of deindustrialization may represent a return to earlier patterns of spatial inequality.

\section{B. Specific Research Questions}

Although it is well known that transportation, soils, and proximity to urban markets were important in creating spatial inequality within the farm sector, the exact contribution of each is not, especially since measures of soil quality have rarely been used in these investigations.

1) How important was soil quality in determining farm values compared with improvements to farmland, transportation networks, and proximity to cities?

2) How did factors affecting wealth in manufacturing differ from those affecting wealth in farming?

3) Were factors affecting county-average individual wealth the same as those in the two sectors we have chosen to analyze, or were they different?

\section{Data}

Our study area was chosen on the basis of where our individual genealogical sample was concentrated: New England, the state of New York and the northern tier of counties in the state of Pennsylvania which were settled by people coming across the state border from New York. This region also corresponds with the area where manufacturing first arose in the United States. Farmers there also responded similarly to competition from Midwestern grain production by specializing in dairying and production for urban markets. It is also a region that is united culturally due to the fact that the first settlers of southern New England originated in England in 
the $17^{\text {th }}$ century. Their descendants moved first North and then West through New York State (Matthews 1962).

Most of the discussion of contemporary inequality has relied upon measures of individual income (Kuznets 1955, Mazumder 2005, Solon 1992, 1999, 2002) but our study focuses upon wealth because that is what is available at the individual level for 1860 . The variables all come from the US Census and are available through the National Historical Geographic Information System (Minnesota Population Center 2011; http://www.nhgis.org). The 1860 census was the first one to ask individuals about both real and personal property and this is why we focus on this date.

The earlier literature focused on spatial units that were either very large (entire countries) or very small (metropolitan areas). But recently, several scholars have studied inequality, poverty and incomes in the United States at the sub national level using counties as their unit of analysis (Curtis et.al. 2012, Mollner et.al. 2009, Peters 2012). Analysis at the county level allows one to analyze spatial differences within countries, and gives full weight to the rural areas (Labao et.al. 2007). The summary volumes (U.S. Bureau of the Census 1864a; 1864b; 1866) reported the results aggregated to the county level. We divided this figure by the total population to analyze wealth per capita. Unfortunately we are unable to study inequality directly as can be done today. The census samples from the $19^{\text {th }}$ century are too small to provide enough coverage of counties and the only census available in its entirety, 1880, did not ask about individual wealth. Also, in contrast to contemporary work, we are studying wealth, not income or wages. Historians who have compared wealth with income for the same individuals at a similar time period have concluded that wealth was more stable over time than was income (Kearl and Pope 1984, 1986a, 1986b).Value of farm land per acre, was available at the county level from the census of agriculture, which asked individual farmers about their acreage and the value of their farms. We also chose capital invested in manufacturing, taken from the census of manufacturing which we divided by the county population. The independent variables we study are also taken from the 1860 summary census figures available from the National Historical GIS. These are described more fully in the analysis section.

\section{Soil Quality}

In the analysis to follow, we use a general measure of soil quality which is available for most of the contemporary US, the Land Capability Classification (Soil. Survey Staff, U.S. Department of Agriculture). The US Soil Conservation Service began to develop this classification system during the 1930's (Helms 1992). Early conservationists envisioned "a system of cultivation under which land would be used without deterioration" (Helms 1992:2). Therefore they ranked soils by how easily they would erode. "The criteria for placing a given area in a particular class involve the landscape location, slope of the field, depth, texture, and reaction of the soil." (Helms 1992:1) The appearance of the soil was important but it was not analyzed chemically. Soils in higher number classes required more careful management. We use the proportion of soils in the top three categories as an index of soil quality. These three are the three that are "suitable for regular cultivation with proper rotations and treatments (Hockensmith 1948: 153). "The safe use of Class IV "is very limited by natural features such as slope, erosion or adverse climate. As a rule its best use is for pasture or hay, but some of it may be cultivated occasionally with proper safeguards (Hockensmith 1948: 154)." By selecting only the top three classes, we have emphasized cropping over grazing. We expect this measure to be positively related to both per capital wealth and farm value per acre.

There are a few counties in New England where the data is not complete and those show up as white on the map to follow: Franklin County Massachusetts and Essex County in northern Vermont. We also eliminated several counties where the survey was not complete, many of which were urban and small and so do not show up on our maps. But the results for several 
counties we did include may have been influenced by the low proportion of soils that had been categorized. (See Appendix One for a list of the counties without information on soils, those which were incomplete, and a fuller description of the classification.)

Interestingly in 1948, Hockensmith, then head of the Survey Division of the Soil Conservation Service, suggested that the capability classes be used for the purpose of tax assessment (1948). He felt they bore at least some relationship to land "value" and he divided the determinants of value into the "permanent" geographic factors and the more temporary "economic" factors. In the 1990's the classification was used by scholars to analyze land use, erosion, and changes in land prices in the US Midwest. One study in the Corn Belt found that distance from markets rather than soil quality explained the changes in land prices between 1969 and 1987 (Benirschka and Binkley 1994). Another study showed that the LCC was useful in predicting the effect of price supports for milk in southwestern Wisconsin. Lowering those supports would mean less erosion because the lowest capability classes would be removed from milk production (Plantigna 1996).

Map 1 shows the proportion of soils in the top three categories by county. Soils in New York were of much higher quality than those in New England. A few counties in New England Bristol and Newport, Rhode Island - had soils which were equally good but they do not show up well on the map as they were small. In New England the better soils were to be found along the coast and rivers such as the Hudson River, and also around Lake Champlain. The high proportion in northern Maine is not accurate because much of the soil in these counties was not surveyed. (See Appendix 1.)

\section{E. A Preliminary Measure of Spatial Inequality}

The Gini coefficient is commonly used to describe inequality at the individual level. It computes the cumulative proportion of total income earned by the cumulative proportion of the population, ranging from $\mathrm{O}$ to 1 , with lower figures representing greater equality. Here we compute a similar measure for spatial inequality. It is the cumulative proportion of each of our measures of wealth held by the cumulative proportion of counties in our study. Manufacturing was more concentrated spatially at the county level (.63) thanfarming (.38) and property held by individuals fell in between (.44). This is to be expected since individual property combined both wealth in farms and other forms of property. Since a great deal of individual property was in farms, it is also to be expected that it would be closer to the figure for farming than for manufacturing.

Of course this measure is a great oversimplification. The counties are not equal in population or in physical extent. Table 1 shows the share of other economic characteristics held by counties in the top $10 \%$ of farm value, manufacturing capital and county-average individual wealth. Again, wealth in farms and individual property were more equally distributed spatially than capital invested in manufacturing, but even so the richest $10 \%$ of the counties in farm value had $25 \%$ of the wealth in farms and the richest $10 \%$ of the counties in individual wealth had $27 \%$ of that wealth. This share was equal to their share of the population, but these wealthy counties only occupied about a tenth of the land area. Capital invested in manufacturing was quite unequally distributed spatially: the top $10 \%$ of counties had half the total capital invested in manufacturing but only $24 \%$ of the population. Foreign born were more concentrated in counties that were high in individual property, perhaps because they worked in domestic service or because they were attracted to more wealthy areas for other sorts of work.

This table includes only the counties in our statistical models. The most urban counties, which contained Boston and New York City, were excluded due to lack of information on their soils. There is every reason to believe that if they were included there would be even more spatial inequality. Middlesex County in Massachusetts, just outside of Boston, was the wealthiest county among those included in our study, having the 
Table 1. Share of Other Economic Characteristics held by the top 10\% of Counties in each form of Wealth in our Study

\begin{tabular}{|c|c|c|c|}
\hline & $\begin{array}{l}14 \text { counties with } \\
\text { the most valuable } \\
\text { farms }\end{array}$ & $\begin{array}{l}14 \text { counties with the most } \\
\text { capital invested in } \\
\text { manufacturing }\end{array}$ & $\begin{array}{l}14 \text { counties with the } \\
\text { most individual wealth }\end{array}$ \\
\hline Share of wealth & $25 \%$ & $51 \%$ & $27 \%$ \\
\hline Share of population & $22 \%$ & $24 \%$ & $23 \%$ \\
\hline Share of land area & $11 \%$ & $8 \%$ & $8 \%$ \\
\hline $\begin{array}{l}\text { Share of urban } \\
\text { population }\end{array}$ & $32 \%$ & $58 \%$ & $57 \%$ \\
\hline $\begin{array}{l}\text { Share of foreign born } \\
\text { population }\end{array}$ & $33 \%$ & $34 \%$ & $41 \%$ \\
\hline
\end{tabular}

Note: To create this table we ranked the 144 counties in our study according to the total value of farms, capital invested in manufacturing and individual wealth and then calculated the share of the other variables the top 14 held.

most capital invested in manufacture and ranking $4^{\text {th }}$ among all the counties in the value of farms.

Gini coefficients calculated for wealth of individuals at this time were higher:.66 for real estate and.83 for total wealth of free adult males,.65 for total wealth in rural areas of the Northeast, which was a bit higher than in the more recently settled regions of the US at the time (Pope 2000:129, 132). Individual level coefficients are always higher than coefficients based upon larger units of analysis because the larger units mask the variation among the individuals within them.

These conclusions are supported by the maps of the three dependent variables. In these maps counties with low or missing values for soil quality are white and the quartiles are in shades of brown. Investment in manufacturing (Map 5) is concentrated in southern New England and a few counties on the coast of Maine. Farm values (Map 4) were highest in both the hinterlands of cities and along the major waterways: Champlain/Hudson waterway and Erie Canal and in one county along the Connecticut River. Individual property per capita (Map 6) is a compromise between the two with the Erie Canal, hinterlands of cities and also western Connecticut having high values. There were a few others which were high in individual property: Rutland
County Vermont was located where a canal linked the Hudson River with Lake Champlain. The high county in Maine is probably an outlier due to small numbers.

\section{METHODS}

\section{A. Bayesian Spatial Analysis}

Contemporary spatial analyses of inequality and of poverty have used both multilevel analysis (e.g. Moller, et. al. 2009), exploratory methods (e.g. Peters 2012), and spatial error regression techniques (Curtis, et.al. 2012). Bayesian methods are now being used widely in social and biological sciences. Although they have not yet been used to study these questions,. they have great potential for flexible modeling of complex data. This flexibility derives from a number of factors. First, multilevel hierarchical models can be accommodated easily in the Bayesian paradigm, and extra variation in data (due to confounding or other factors) can easily be incorporated. This includes both spatially correlated and uncorrelated effects (see e. g. Lawson, 2009, ch 5; Lawson and Banerjee, 2010, Lesaffre and Lawson, 2012, ch 16). The ability to specify random effects with flexible prior distributions means that considerable complexity can be incorporated within one model. It is also 
possible to assess prior sensitivity and to check for assumption dependence in the resulting analysis. This is not available in the equivalent frequentist analysis, which assumes uniform prior distributions for all parameters. A frequentist approach is hence inflexible and precludes such liberal modeling choices. The Bayesian paradigm also benefits from posterior sampling which provides a wealth of information about the characteristics of parameter variation, unlike frequentist analyses which only provide point estimates. The availability of software for such analyses, in particular WinBUGS and increasingly SAS and INLA, helps to provide access to the methods. In our analyses we exploit the advanced features of WinBUGS with GeoBUGS to analyze the spatial distribution of wealth.

Our basic model assumed has the following ingredients. First we denote the outcome (either wealth per capita, farm value per acre, or manufacturing per capita) as. We also assume that the chosen outcome has a mean level observed with noise and hence we assume a Gaussian distribution for the error: $\mathrm{y}_{\mathrm{i}}=\mathrm{N}\left(\mu_{\mathrm{i}}, \sigma\right)$. The mean level is parameterized with a range of fixed and random effects. In general, we define $\mu_{i}=\alpha_{0}+x_{i}^{T} \alpha+\Lambda$ where $\alpha_{o}$ is an intercept, $X_{i}^{T}$ is a predictor vector, $\alpha$ is a corresponding parameter vector and $\Lambda_{\mathrm{i}}$ is a random effect set.

The random effect set usually includes two additive components addressing spatial effects: uncorrelated heterogeneity (UH) and correlated heterogeneity $(\mathrm{CH})$. Hence, we assume that $\Lambda_{\mathrm{i}}=$ $V_{i}+W_{i}$, where the $V_{i}$ is the UH effect and the $W_{i}$ is the $\mathrm{CH}$ effect. These effects are designed to allow for unobserved confounding in the data (both correlated and otherwise). We further assume the following relatively non-informative prior distributions for parameters and effects. All regression parameters are assumed to have zero mean Gaussian distributions with uniform prior distributions for their SDs, i.e. $\alpha_{*}=\mathrm{N}\left(\mathrm{o}, \sigma_{\left(\alpha_{i}\right)}^{2}\right)$; $\sigma_{\left(\alpha_{i}\right)}=\mathrm{U}(\mathrm{o}, \mathrm{c})$ (Gelman, 2006).

In addition,

$$
V_{i}=N\left(0, \sigma_{\left(\alpha_{i}\right)}^{2}\right) ; \sigma_{V}^{2}=U(0, c)
$$

and conditionally defined

$W_{i}=N\left(\bar{W}_{\left(\delta_{i}\right)}, \sigma_{W}^{2} / n_{\left(\delta_{i}\right)}\right)$ where $\delta_{\mathrm{i}}$ is a spatial neighborhood of the ith county, $n_{\left(\sigma_{i}\right)}$ is the number of neighbors and $\bar{W}_{\left(\delta_{i}\right)}$ is the mean of $\mathrm{W}$ in the neighborhood, i.e. $\bar{W}_{\left(\delta_{i}\right)}=\sum_{\left(j \in \delta_{i}\right)} W_{j} / n_{\left(\delta_{i}\right)}$

This latter prior distribution is a conditional autoregressive (CAR) model and specifies a Markov random field for $\left\{\mathrm{W}_{\mathrm{i}}\right\}$. Hence, based on the neighborhood adjacencies this effect encapsulates the spatially correlated effect found in the outcome. In general, we assume that standard deviations of effects have uniform prior distributions, i.e. $\sigma_{*}=\mathrm{U}(\mathrm{o}, \mathrm{c})$.

When fitting Bayesian models via posterior sampling (using WinBUGS) it is important to consider convergence of the samples and to only utilize converged sample values for parameter estimates. In our model we always check convergence using Brooks-Gelman-Rubin (BGR) statistics on multiple chains. We found that convergence was reached for all models by 10000 iterations. We then took a sample of size 30000.

To assess model goodness - of - fit we employ the deviance information criterion (DIC) which is a measure of closeness of fit based on the posterior average likelihood deviance and a penalty parameter $(\mathrm{pD})$ which adjusts for the effective number of parameters. The DIC is computed from $D I C=\bar{D}+p D$. In general, the smaller the DIC the better the model fit, and a difference of 3-5 in DIC is regarded as an important model improvement.

In each analysis we tested several models: a model with no spatial effects, using several independent variables described below, a model with a random spatial effect $(v)$, this is an effect specific to a particular county, and a model with correlated spatial effects $(w)$. This model tests whether the unexplained variation in the model is spatially correlated by comparing the unexplained variation with contiguous counties. 
The relative effectiveness of these models is measured by the DIC. In all cases the model with both correlated and uncorrelated spatial effects had a DIC dramatically lower than the other two models. Thus there were both correlated and uncorrelated spatial effects over and above the variables included in the models, many of which were spatial themselves. The analysis generates maps of both the correlated and uncorrelated spatial effects which can be examined for patterns that indicate spatial effects that were not included in the analysis. First we tried models with only main effects but because there seemed to be significant differences in the values of the independent variables depending on the level of the canal variable, we also looked at interactions between the canal variable and four other variables. These models had lower DIC's than those with only the main effects and it is the models with the interactions that we present here.

\section{B. Variables used in the analyses}

The independent variables were the same for the three analyses and included variables summarizing the population, the land and proximity to markets. Three variables reflected the composition of the population in a county. Percent urban is the proportion of the population living in places with 2500 or more inhabitants, a very low threshold which, however, has become the accepted measure (see U.S. Bureau of the Census, 2012, Chapter 12). We hypothesized that the more urban the county the less wealth there would be per capita because cities had many poor residents who owned little property. The same was true of the percent foreign born. The greater the share of the population born elsewhere the poorer the county should be because they would not have had the same time to accumulate wealth as the native population and so much of the wealth was in farms which were owned by native born. Because percent urban was also included in our models, the effect of large settlements would be controlled for and thus population density reflected rural density and in counties where farming predominated it should reflect the profitability of farming and thus be positively associated with farm values. The counties with the largest cities, New York and Boston, are not included in our analysis because there was no information on their soils.

The two variables related to the land were the proportion of improved farm acreage in the county and our measure of soil quality. Improved acreage would have been worth more than unimproved acreage.

Five variables captured proximity to markets. We included a variable which was the natural log of distance from the center of the county to New York City or to Boston, whichever was smaller. This was to measure the opportunity for farmers to produce products for these large cities. It was logged because the effect would be stronger closer to the large cities. Meyer (2003) describes a ring around Boston of 50 miles where farmers were producing for the city. Four variables reflected the availability of different types of transportation: ports, rivers (deep enough for commercial boats to use), canals, and railroads ${ }^{1}$. These all record the presence or absence of a form of transportation in a particular county at a given census year. But because there has been a debate about the importance of minor canals at this time, we separated the major canals, the Erie and the Champlain, from the feeder canals to the Erie and other smaller canals, making the two level variable into three. The Champlain Canal was part of a system connecting New York City with Lake Champlain in Vermont. The system, in our set of variables, includes ports, both on Lake Champlain and New York City, the Hudson River (included in the river variable) and the Champlain Canal. The canals themselves were frequently laid out to make use of rivers - the Erie followed the Mohawk River Valley, the only available path through the mountains and the Champlain Canal was basically a link between the Hudson and Lake Champlain. Wealth per capita was highest in counties with canals (median for these counties was about $\$ 625$ ), about $\$ 575$ in counties with minor canals and about $\$ 500$ in counties without canals. At this time the entire area except for certain marginal parts of northern Maine and the Adirondacks and a few New York counties away from the Erie Canal were 
accessible by train.

In order to understand the roles of the canals more fully we modeled the dependent variables first without interaction terms and then with interactions between canals. The models for all three dependent variables with the interaction terms had a lower DIC than those which did not include them and therefore we report only the models with interactions in the results below.

Population density, percent urban and distance to the closest large city (Boston or New York City) were also interrelated. But we felt that by including all three, percent urban would measure the urban areas, their immediate peripheries would be modeled by distance to the closest city and then the population density variable would measure primarily differences in density between rural areas.

\section{Spatial Analyses}

In what follows we present the parameter estimates for our best models, beginning with the value of farms, then manufacturing capital and finally individual property. In all three cases, the best models included not only the independent variables but also two spatial effects: random and correlated. The random effects are individual effects of being in a specific county. The correlated effects show the effects that are related to values in neighboring counties. At the end of each section we present the maps of these two types of spatial effects. In Appendix Two we provide estimates of how much each effect increases the model fit. Each reduces the DIC a great deal, compared with models without them so the model fit is greatly improved with their inclusion.

\section{BAYESIAN HIERARCHICAL SPATIAL ANALYSES}

Our analyses demonstrate that inequality in wealth between counties was strongly affected by spatial factors, not only those included in our models but also others that were unobserved.
This was true not only of wealth but also of each of the two sectors we analyzed: farming and manufacturing, and, not unexpectedly, the spatial structures differed in the two sectors.

\section{A. Farm Value per Acre}

\section{1) Spatial Distribution and Historical Background}

A comparison of farm values (Map 4) with soil quality (Map 1) shows that areas around cities in southern Massachusetts had high values despite their comparatively poor soils. Even in areas with poor soils, farmers could prosper by specializing in products, such as hay for horses, that were bulky and costly to ship, or were perishable, such as dairy products for urban dwellers or hay for horses. In 1860 New York remained a prosperous agricultural area which was moving from grain production to dairying and sheep (Atack, Bateman and Parker 2000:248; Meyer 2003). Despite the influx of grain from the middle west, the proportion producing for the market in New York rose from $57 \%$ in 1855 to $71 \%$ in 1865 (Parkerson 1995:99). Between 1855and 1865 the Hudson River Valley caught up with those in the Erie Canal in production for the market, probably due to the growth of New York City and its demand for farm products. The East bank of the Hudson had a railroad which allowed milk to be shipped to New York City and its effects can be seen clearly on Map 4.

Meanwhile farms in southern New England away from the major cities were being abandoned. Rhode Island reached its peak of cleared land (woodland as a proportion of upland area) around 1840, Connecticut in 1850, followed by New Hampshire in 1860, Massachusetts in 1870, Maine in 1880 and Vermont in 1900 (Foster and Aber 2004:10). Our measure of value per acre does not capture the consolidation of farms or the removal of land from farming although one would expect that the prices per acre would be lower in areas where farms were being abandoned. This may be the case in a few counties in western Massachusetts but the map of farm values shows the importance of transportation within New England with the 
minor (and supposedly unsuccessful canals) in Maine and in southern New Hampshire and the area around Lake Champlain having comparatively high values.

\section{2) Spatial Analysis of Farm value per Acre}

Table 2 presents our results in detail for both farm values per acre and manufacturing per capita. Since nearly all the variables and interactions were significant we discuss only the important factors, giving special attention to transportation and soils. Table 3 lists the 5 most important factors in each analysis, determined by dividing the mean by the standard deviation. They were then ranked in order of their importance and the rank provided in parentheses. The equivalent values for each of the factors that were among the top 5 in each analysis are also provided for comparison. Table 4 presents a summary of the findings on transportation along with their rank in importance in the complete analysis.

The log of distance to the closest city had the strongest effect upon farm value. Next in importance was population density which was associated with higher farm values especially in counties along major canals. The two soil variables, proportion improved and soil quality were next and about equal in importance.

When the interactions were not in the model, population density was associated with higher farm values, but when we added interactions, the sign turned negative with the interactions of population density with all three levels of canals positive. The larger positive effect of density in counties on major canals shows the great importance of the major canals for farm value even if it is most pronounced in counties with higher density. The area was populated before the canals were built. However, the canals also led to the growth of several smaller cities.

It is hard to evaluate the importance of the different transportation modes because the interaction term takes away from the main effect of canals. But because the interaction terms are so large, it is safe to conclude that the canals alone and in combination with other factors were important in the analysis without interactions, major canals were associated with higher farm values while minor canals were associated with lower farm values compared with no canal at all. But adding interactions with canals showed that it was the percent improved that related most strongly to high farm values. In fact when the interactions were in the model, the difference between having no canal and a major canal was no longer significant. But counties with minor canals had significantly higher farm values than did those with major canals. Thus there was a relationship between the canals and the production for market which indicated by higher proportion improved. Railroads and rivers (these are navigable rivers which were used for shipping) in a county were associated with lower farm values, while ports were associated with higher farm values.

In counties without canals (i. e. mostly in New England) foreign born, percent improved and good soil was associated with higher farm values. In counties with a major canal - these were largely in New York State - population density was associated with higher farm values. And, in counties on minor canals, improving the land was associated with higher farm values.

Foreign born were positively related to farm values, not negatively, as we had expected. Foreign born were concentrated in southern New England and along the borders with Canada. In New York State the counties along the Erie Canal were also the counties with small cities: Buffalo, Rochester, Syracuse, Oneida, Albany and Troy. Farms were not owned by foreign born in this region. The foreign born thus went to areas with prosperous farms probably because they also had cities and they worked either in the cities or as farm laborers.

The maps of the spatial effects may show patterns that are not explained by the covariates in the model. The map of random spatial effects (Map 7) for farm value is random which is to be expected with an appropriate model. In northern Vermont around Lake Champlain and the Albany/Schenectady area, values were higher 
Table 2. Posterior Average Parameter Estimates for best fitting Model of County Farm Value and Manufacturing Capital (including uncorrelated and correlated random effects)

\begin{tabular}{|c|c|c|c|c|c|c|}
\hline \multirow[b]{2}{*}{ Variable } & \multicolumn{3}{|c|}{ Farm Value per Acre } & \multicolumn{3}{|c|}{ Manufacturing capital per cap } \\
\hline & Mean & $\mathrm{SD}$ & Mean/SD & Mean & $\mathrm{SD}$ & Mean/SD \\
\hline Intercept & 0.20 & 1.20 & 0.17 & 0.11 & 1.16 & 0.097 \\
\hline percent urban & $-7.79 *$ & 1.39 & -5.60 & $64.76^{*}$ & 1.45 & 44.79 \\
\hline percent foreign born & $9.06^{*}$ & 1.87 & 4.85 & $11.0 *$ & 1.86 & 5.92 \\
\hline population density & $-0.23 *$ & 0.04 & -5.43 & $-0.58^{*}$ & 0.04 & -13.65 \\
\hline percent farm land improved & $16.08 *$ & 1.57 & 10.23 & $-19.3 *$ & 1.56 & -12.40 \\
\hline proportion good soil & $17.1 *$ & 1.47 & 11.64 & $-25.2 *$ & 1.46 & -17.22 \\
\hline Distance to closest big city & $-8.34 *$ & 0.54 & -15.34 & $-10.9 *$ & 0.58 & -18.85 \\
\hline Diff betw minor and no canal & $5.78^{*}$ & 1.59 & 3.63 & $-3.34 *$ & 1.54 & -2.16 \\
\hline Diff betw major and minor canal & $-3.45^{*}$ & 1.57 & -2.20 & $-10.86^{*}$ & 1.72 & -6.31 \\
\hline Diff betw major and no canal & 2.33 & 1.47 & 1.58 & $-14.2 *$ & 1.63 & -8.73 \\
\hline Diff betw port and no port & $2.84^{*}$ & 0.60 & 4.73 & $-10.82 *$ & 0.66 & -16.32 \\
\hline Diff betw river and no river & $-2.12 *$ & 0.67 & -3.16 & $-9.52 *$ & 0.68 & -14.00 \\
\hline Diff betw railroad and no & & & & & & \\
\hline $\begin{array}{l}\text { railroad } \\
\text { Interaction of foreign born with }\end{array}$ & $-3.98 *$ & 0.77 & -5.19 & -0.72 & 0.73 & -0.99 \\
\hline No canal & $6.54 *$ & 2.02 & 3.23 & $9.58^{*}$ & 1.93 & 4.95 \\
\hline Minor canal & 0.46 & 1.79 & 0.26 & 0.85 & 1.86 & 0.46 \\
\hline Major canal & 1.55 & 1.85 & 0.84 & 0.36 & 1.89 & 0.18 \\
\hline Interaction of population density & & & & & & \\
\hline No canal & $0.35^{*}$ & 0.04 & 8.59 & $0.76^{*}$ & 0.04 & 18.44 \\
\hline Minor canal & $0.37 *$ & 0.04 & 8.65 & $0.61 *$ & 0.04 & 14.62 \\
\hline Major canal & $0.54^{*}$ & 0.04 & 12.62 & $0.84 *$ & 0.04 & 20.06 \\
\hline Interaction of percent improved & & & & & & \\
\hline No canal & $6.99 *$ & 1.66 & 4.21 & $-10.59 *$ & 1.61 & -6.57 \\
\hline Minor canal & $6.48^{*}$ & 1.81 & 3.58 & $3.63 *$ & 1.72 & 2.10 \\
\hline Major canal & 2.14 & 1.72 & 1.24 & $-12.14 *$ & 1.76 & -6.89 \\
\hline Interaction of $\%$ good soil with & & & & & & \\
\hline No canal & $13.32 *$ & 1.52 & 8.78 & $-15.59 *$ & 1.53 & -10.22 \\
\hline Minor canal & 3.25 & 1.74 & 1.87 & -2.66 & 1.66 & -1.60 \\
\hline Major canal & 0.48 & 1.75 & 0.28 & $-6.45^{*}$ & 1.70 & -3.80 \\
\hline
\end{tabular}

*Statistically significant.

than the model predicted. Lake Champlain might be explained by trade with Canada or these counties might have been part of the large agricultural hinterland of New York City. The Albany area was the third largest urban area at the time behind New York and Boston (Meyer2003:217). Since our model only included distance from Boston or New York City, it makes sense that farm values there were higher than the model predicted.

The map of correlated spatial effects (Map 8) shows four zones. On the eastern and western edges of the study area, farms form a cluster of lower than average value (except for the counties along Lake Erie which also were on the Erie canal).In the middle of the map in western Vermont and the Adirondack area of New York 
Table 3. Summary Table: Means of the 5 most Important Factors in each Analysis

\begin{tabular}{|c|c|c|c|}
\hline & $\begin{array}{l}\text { Farm Value per Acre } \\
\text { (rank order) }\end{array}$ & $\begin{array}{l}\text { Manufacturing } \\
\text { (rank order) }\end{array}$ & $\begin{array}{l}\text { County-average } \\
\text { Individual Wealth } \\
\text { (rank order) }\end{array}$ \\
\hline Distance to Closest big City & $-8.3 *(1)$ & $-10.9 *(3)$ & $-53.3 *(6)$ \\
\hline $\begin{array}{l}\text { Population Density and having a } \\
\text { Major Canal }\end{array}$ & $0.54 *(2)$ & $0.8 *(2)$ & $8.2 *(1)$ \\
\hline Proportion Good Soil & $17.1 *(3)$ & $-25.3 *(5)$ & $121.8 *(7)$ \\
\hline Percent farm land improved & $16.1 *(4)$ & $-19.3 *(10)$ & $233.1 *(3)$ \\
\hline $\begin{array}{l}\text { Proportion good soil and having } \\
\text { no canal }\end{array}$ & $13.3 *(5)$ & $-15.6 *(11)$ & $75.5 *(11)$ \\
\hline $\begin{array}{l}\text { Population density and having a } \\
\text { minor canal }\end{array}$ & $0.4 *(6)$ & $0.6^{*}(7)$ & $7.1 *(2)$ \\
\hline $\begin{array}{l}\text { Population density and having no } \\
\text { canal }\end{array}$ & $0.35 *(7)$ & $0.8^{*}(4)$ & $6.8 *(4)$ \\
\hline Percent urban & $-7.8 *(8)$ & $64.8 *(1)$ & $-42.05 *(15)$ \\
\hline Population Density & $-0.2 *(9)$ & $-0.6 *(9)$ & $-6.8 *(5)$ \\
\hline
\end{tabular}

Notes: The table gives the means from the analysis. The top 5 effects in importance are included for each analysis. The rank order of importance was determined by the mean divided by the standard deviation. The mean and rank order of those not in the top 5 for a particular analysis are included for comparative purposes. The order of the variables follows the order of their importance for farm value. $*=$ statistically significant result.

and the Albany/Schenectady area farms form a cluster of higher than average value while most of the eastern part of New England is well predicted. Our model does not take the larger size of New York compared with Boston into account so the central area around the Hudson/Champlain waterway probably represents the larger hinterland producing for the New York market. Interestingly many counties on the Erie Canal form a cluster of lower than average value.

In farming then, proximity to urban markets and water transport had very strong effects upon land values, but soil quality was important even after these variables were controlled. There was little an individual could do except to improve soils which had a greater effect in counties on minor canals. In areas along major waterways, it was the greater proportion improved that led to higher farm values not simply being on the canal itself.

\section{B. Manufacturing per Capita}

1) Spatial Distribution and Historical

\section{Background}

Numerous small (and not-so-small) rivers flowing through southern New England provided the cheap and easily-harnessed power source demanded by the earliest mills. The year 1790 tentatively marks the start of true industrialization, as it is around this time that three important mills became operational: Samuel Slater's cotton spinning mill in Pawtucket, Rhode Island, the Springfield Armory on the Connecticut River in Springfield, MA, and the jenny cotton mill in Beverly, MA (Clark 1929). Water power utilized rivers that were often not navigable because they harnessed the falls, places that were not useful for shipping agricultural products. Thanks to improvements in the design of the overshot water-wheel, smaller flows could often supply sufficient power to run the necessary machinery for most small and medium-sized enterprises. One mill's use of the resource had little effect on other mills a short distance downstream. Perhaps most importantly, it was cost-effective in comparison with regions with ready access to coal such as much of 
Table 4. Summary Table of Transportation Effects: Main Effects and Interactions

\begin{tabular}{|c|c|c|c|}
\hline & Farm Value per Acre & Manufacturing & Individual Wealth \\
\hline \multicolumn{4}{|l|}{ Main Effects } \\
\hline $\begin{array}{l}\text { Difference between minor canal } \\
\text { and none }\end{array}$ & $5.8 *(12)$ & $-3.3 *(18)$ & $16.6^{*}(9)$ \\
\hline $\begin{array}{l}\text { Difference between major and } \\
\text { minor canal }\end{array}$ & $-3.45 *(15)$ & $-10.9 *(14)$ & $-10.7 *(21)$ \\
\hline $\begin{array}{l}\text { Difference between major canal } \\
\text { and no canal }\end{array}$ & 2.3 & $-14.2 *(12)$ & $5.8 *(23)$ \\
\hline Difference between port and none & $2.8 *(10)$ & $-10.8 *(6)$ & $27.22 *(12)$ \\
\hline Difference between river and non & $-2.1 *(13)$ & $-9.5 *(8)$ & $25.45 *(10)$ \\
\hline $\begin{array}{l}\text { Difference between railroad and } \\
\text { none }\end{array}$ & $-4.0 *(9)$ & -0.7 & $45.6 *(9)$ \\
\hline \multicolumn{4}{|l|}{ Interaction Effects } \\
\hline \multicolumn{4}{|l|}{ Foreign born } \\
\hline No canal & $6.54 *(14)$ & $9.58 *(16)$ & 0.27 \\
\hline Minor canal & 0.46 & 0.85 & $24.49 *(17)$ \\
\hline Major canal & 1.55 & 0.36 & $-14.86 *(20)$ \\
\hline \multicolumn{4}{|l|}{ Population Density } \\
\hline No canal & $0.35 *(6)$ & $0.76 *(4)$ & $6.84 *(4)$ \\
\hline Minor canal & $0.37 *(5)$ & $0.61 *(7)$ & $7.13 *(2)$ \\
\hline Major canal & $0.54 *(2)$ & $0.84 *(2)$ & $8.25 *(1)$ \\
\hline \multicolumn{4}{|l|}{ Percent Improved } \\
\hline No canal & $6.99 *(11)$ & $-10.59 *(16)$ & $80.95 *(12)$ \\
\hline Minor canal & $6.48 *(13)$ & $3.63 *(19)$ & $105.5^{*}(8)$ \\
\hline Major canal & 2.14 & $-12.14 *(13)$ & $46.76 *(5)$ \\
\hline \multicolumn{4}{|l|}{ Good Soil } \\
\hline No canal & $13.32 *(4)$ & $-15.59 *(11)$ & $75.7 *(11)$ \\
\hline Minor canal & 3.25 & -2.66 & $26.54 *(16)$ \\
\hline Major canal & 0.48 & $-6.45 *(17)$ & $19.62 *(19)$ \\
\hline
\end{tabular}

Rank order of magnitude of the significant effects on the dependent variable given in parentheses.

$*$ = statistically significant result

Pennsylvania (one downside to water power was the fact that small streams generally froze in the winter, thus limiting production during these months). It is not surprising; therefore, that manufacturing was concentrated in areas which had rivers that were not useful for shipping.

By mid-century, New England was producing the vast majority of the nation's textile products, three-quarters by some estimates (Meinig 1993: 380). The nation's first firearms manufacturing center formed part of an expanding region, centered largely in Connecticut, that specialized in machined products, small-scale metalworking, and artisan-type goods such as locks, rolled brass and tin products, and clocks. Samuel Colt began producing rifles in Hartford about this time. Connecticut also developed a niche textile industry largely focused on items such as hats, gloves and hosiery. The region in central Massachusetts around Greenfield, Gardner and Fitchburg supported a prosperous furniture, cabinetry and general small-scale woodworking trade. Shoemaking and shoe machinery 
manufacturing became established near the coast in Lynn and the general area of Boston's North Shore.

New England was relatively slow to adopt the steam engine upon its introduction around 1830, and even when it did, steam power was much more expensive than in more coal-rich regions. Conversion to steam power meant freedom from the necessity of locating one's operation on a waterway in an often rural area, so that manufacturing could be carried on much closer to urban areas - providing access to local markets, as well as transshipment points for interstate commerce. Still, as late as 1870 half of New England's power came from water, not steam (Engerman and Sokoloff 2000: 374).

\section{2) Spatial Analysis of Capital Invested in Manufacturing per capita}

Still, the most important predictor of manufacturing per capita, was the percent urban (relationship is positive, see Table 2), which had been negatively associated with farm value. Since the threshold for urban was very low - $2500-$ this did not necessarily reflect the largest cities. Next in importance was the combination of being on a major canal and population density, which also was important in explaining farm values (and positively related). Like the larger cities, the smaller cities along canals were becoming a focus both for farming and manufacturing (and commerce, not included in our analysis). Population density as a main effect was also negatively associated with investment in manufacturing, as it was also with farm value. After percent urban is taken into account, this variable reflects rural density. These effects of population are difficult to interpret. Possibly the large effect of percent urban has completely dwarfed population density to the extent that it had a negative relationship with manufacturing investment. Being near either Boston or New York was associated with more investment in manufacturing, about to the same degree as it was with higher farm values. Thus, the hinterlands of cities were complex: they contained both manufacturing and farms of high value.
Being on transportation routes, no matter of what type, reduced the capital invested in manufacturing in a county. Having a port and being on a navigable river and not being on a canal (compared with being on a major canal) deterred investment in manufacturing. Recall that although many factories used water power from rivers, this variable codes rivers that could have been used for shipping goods. The difference between having a railroad in the county or not was not statistically significant for investment in manufacturing.

This confirms Meyer's ideas that wagons were crucial to bringing manufactured goods to market. They were taken to ports on waterways or to urban centers. Again the effect of canals was complex. All of the main effects were negative, with having no canal reducing the manufacturing investment the most compared with being on a major canal. The least difference was between minor and no canal. Thus there is some evidence for manufacturing being located in counties with major canals. Meyer points out those smaller cities that grew up along the Erie Canal had manufacturing. As we have seen proportion urban was the most important determinant of manufacturing.

The reason for these effects might lie in the differences between New England and New York in the location of manufacturing. In New York, it was located along major waterways, but in New England it avoided them. In the case of soil quality, the signs did not change depending on whether the county had a canal but the negative relationship between good soils and manufacturing was much greater in counties with no canals than in counties with them reflecting the concentration of manufacturing in New England where there were few canals. Also the percent foreign born led to more manufacturing investment only in counties without canals, i.e. mostly in New England. In counties without canals, percent improved and good soil was associated with less investment in manufacturing. This is probably primarily in New England. In counties with major canals, population density was associated with more investment in 
manufacturing and percent improved soil with less. So even along canals there was a negative relationship between soils and manufacturing. Again it is not clear whether manufacturing located there because of high density or it brought people to the county. The commercial activity associated with canals also brought people to the county.

The map of the uncorrelated spatial effects (Map 9) indicates that we have done a good job at explaining the effects since the unexplained variation appears random. Again, the set of counties around Albany, Schenectady etc. had more capital invested in manufacturing than the model predicted as did a group of counties in Western CT.

In contrast, the map of the correlated spatial effects (Map 10) displays clear differences between New York State and New England. Most of New York State has a cluster of lower than average capital invested in manufacturing. The exception is the group of counties around Albany/ Schenectady. Some of the dark areas in northern Maine and in northern Vermont are clustered with higher capital invested, probably because logging was considered manufacturing. In general, then, despite the variables already in our models, including soil quality, we have not explained the difference between New York and New England. Of course the nature of the rivers needed for water power is not in the model, but there also could have been other regional characteristics which could explain the difference such as the existence of a skilled labor pool in New England, or capital available for investment, perhaps due to the prosperity of farms or commerce there.

\section{County Average Individual Property}

\section{1) Spatial Distribution and Historical Background}

Individual property is not simply a combination of the previous two analyses because certain sources of individual wealth were not included in them. On average $38 \%$ (county median $=46 \%$ ) of the wealth of a county was in farms. According to Margo (2000:214), the manufacturing sector employed the largest share of workers outside of agriculture (37\%) nationally and that rate was probably quite a bit higher in the Northeast. The most important source of wealth left out of our study so far was the commercial sector (see, for example, Margo 2000: 215). There is no measure of this available from the census in 1860 .

Still one would expect that an analysis of countyaverage individual wealth would look a lot like the farm analysis and that differences might be due to wealth from commerce. The importance of wealth from commerce, missing from our analysis, might be visible in the high values of wealth along the Hudson/Champlain waterway (but only on the Eastern bank where the railroad ran) and in the large hinterland of New York City, or perhaps in Western Vermont (compare Map 4 with Map 6). Surprisingly, average individual wealth was not consistently higher in the hinterland of Boston. This could have been due to the large number of foreign born that had settled there who were comparatively poor.

\section{2) Spatial Analysis of County-Average Individual Wealth}

The signs for the main effects were the same as in the farm value analysis for all the variables except the presence of rivers and railroads both of which were positively associated with county-average individual wealth but were negatively associated with farm values. These probably increased wealth from commerce, not captured in either of our earlier analyses. Looking only at the top five effects, two were shared with farm value - percent of land improved and the interaction of density and being on a major canal, which was also important in explaining manufacturing investment. Good soil was associated with more individual wealth, more so in counties without canals (primarily in New England), similar to their relationship to farm value. In both the analyses density had a negative effect upon wealth, which was not what we expected but the interaction of the canals with density was important and positive in both analyses and the effects stronger upon wealth than upon farm 
values. In fact, the strongest effect of all in the model for county-average individual wealth was the interaction between population density and being on a major canal. (In the analysis of farm value it was the second strongest effect.) Density is probably a predictor of wealth from commercial activity within urban areas.

The importance of the two soil variables in explaining individual wealth confirms that the farm sector dominated the economy and farms were the most important form of wealth. Percent urban was negatively related to wealth which we expected because so much wealth was in farms. Apparently the greater variation in wealth in urban counties did not result in the high values swamping the rest. But it was surprising that percent foreign born was positively related to wealth since recent arrivals should have been less wealthy than those who had been in the US a longer time. However they may have settled in places with wealthier individuals.

Transportation had larger and more positive effects upon wealth than it did upon farm values. But the interaction effects may mask the main effects of canals. In fact the interactions of canals and other variables were stronger for wealth than they were for farm value reflecting the commerce along canals. Of the other transport variables, railroads had the largest effects upon wealth, followed by ports and rivers whose effects were nearly equal.

The map of the uncorrelated effects (Map 11) looks nearly random. But the map of the correlated effects (Map 12) is quite different from the maps for manufacturing and for farm value, both of which had areas along the Hudson/Champlain waterway displaying clustered elevated wealth. Instead, areas of both low and of high wealth appear on the edges of the map. Northern Pennsylvania displays a cluster of elevated wealth. Another such area was on the border of New Hampshire and Maine. Counties along the Canadian border in New York display a cluster of lower than average wealth. But an area in Connecticut and Rhode Island was wealthier than average and, because this does not appear in the map of farm values, here was probably one case where we can see the effect of the manufacturing clustered in this area upon average individual wealth. Another area with clustering of elevated wealth was in central New York along the Erie Canal, an area where there was probably a lot of wealth in commerce.

To conclude, there were important differences in county-average individual wealth among counties due to transportation, proximity to cities and soil quality. These factors, largely beyond the control of individuals or families, affected wealth at a county level. Farmers, especially those in counties on minor canals and those without canals, were able to increase their wealth by improving their land. At this time, most of the land in farming had been taken up and it would have been difficult to move from areas where land was cheap to those where it was more expensive. An option taken by many was to work in manufacturing or commerce.

It is striking that the effects of manufacturing are not more visible in the analysis of countyaverage individual wealth (Compare Maps 5 and 6). Wealth was recorded from individuals living within the counties but the capital invested in manufacturing could have been held by individuals living elsewhere. In fact the census stopped tabulating and reporting individual wealth in 1870 by county partly for this reason. Even if the wealth came from within those counties, its distribution would be quite skewed. The larger number of workers with little wealth might have cancelled out the wealth of the owners. There were, indeed, several counties with high investment in manufacturing but low per capital wealth: two counties in southern New Hampshire where there were large mills, two counties along the Connecticut River in Massachusetts.

\section{DISCUSSION AND CONCLUSIONS}

\section{A. Discussion of Findings}

Soils were a surprisingly important, though not the most important, determinant of wealth. One could improve land and raise the value of one's 
Table 5. Posterior Average Parameter Estimates for best fitting Model of County Average it Individual Property (including uncorrelated and correlated random effects)

\begin{tabular}{|c|c|c|c|}
\hline \multirow[b]{2}{*}{ Variable } & \multirow[b]{2}{*}{ Mean } & \multicolumn{2}{|c|}{ Wealth per Capita } \\
\hline & & $\overline{\mathrm{SD}}$ & Mean/SD \\
\hline Intercept & 0.11 & 1.17 & 0.097 \\
\hline Percent urban & $-42.05^{*}$ & 1.44 & -29.16 \\
\hline Percent foreign born & $9.13^{*}$ & 1.87 & 4.87 \\
\hline Population density & $-6.81 *$ & 0.05 & -143.98 \\
\hline Percent farm land improved & $233.1 *$ & 1.57 & 148.96 \\
\hline Proportion good soil & $121.8 *$ & 1.46 & 83.71 \\
\hline Distance to closest big city (log) & $-53.28 *$ & 0.59 & -90.88 \\
\hline Diff betw minor and no canal & $16.57 *$ & 1.58 & 10.51 \\
\hline Diff betw major and minor canal & $-10.73 *$ & 1.71 & -6.27 \\
\hline Diff betw major canal and nocanal & $5.84^{*}$ & 1.61 & 3.63 \\
\hline Diff betw port and no port & $27.22 *$ & 0.67 & 40.82 \\
\hline Diff betw river and no river & $25.45^{*}$ & 0.68 & 37.59 \\
\hline Diff betw railroad and norailroad & $45.58 *$ & 0.81 & 56.54 \\
\hline Interaction of foreign born withNo canal & 0.27 & 1.87 & 0.15 \\
\hline Minor canal & $24.49 *$ & 1.95 & 12.58 \\
\hline Major canal & $-14.86 *$ & 1.97 & -7.54 \\
\hline Interaction of population densityNo canal & $6.84 *$ & 0.05 & 146.56 \\
\hline Minor canal & $7.13^{*}$ & 0.05 & 150.27 \\
\hline Major canal & $8.25^{*}$ & 0.05 & 174.21 \\
\hline Interaction of percent improvedNo canal & $80.95 *$ & 1.64 & 49.42 \\
\hline Minor canal & $105.5 *$ & 1.74 & 60.53 \\
\hline Major canal & $46.76^{*}$ & 1.75 & 26.66 \\
\hline Interaction of \% good soil withNo canal & $75.7 *$ & 1.50 & 50.57 \\
\hline Minor canal & $26.54 *$ & 1.69 & 15.75 \\
\hline Major canal & $19.62 *$ & 1.70 & 11.51 \\
\hline
\end{tabular}

*Statistically significant result

farm particularly in the areas away from the major canals. Still, other factors, more out of farmers' control, like proximity to cities had a greater effect. Our decision to use the top three rather than the top four soil classes might have affected this result. If pasturage and soils suitable only to grow hay had been included, possibly soil quality might not have been as important.

The two sectors studied in this paper differed in both the degree of spatial inequality and its determinants. Wealth in manufacturing was more concentrated than wealth in farming as one would expect in a region where manufacturing had begun only 60 years earlier, particularly since relied upon rivers for power. To be sure in both the farm and manufacturing sectors wealth was concentrated in cities and in areas with more foreign born. Also being on a major canal and having a high population density was important in both. But in other respects, manufacturing was truly an alternative to farming spatially, located exactly in those areas where conditions for farming were poor, whether those were the quality of the soil, the proximity to transportation, the proportion of the population that was urban orof soils that were improved. This at least indirect support for one theory for why manufacturing arose first in New England rather than elsewhere in the United States: the 
surplus labor available when grain production moved, first, out of New England and later out of New York, as the Midwest, with its more productive soils, was settled (Field 1978; Goldin and Sokoloff 1985). Whether the mills brought people or mills located there because of available labor, probably changed over time. At first, mills located along rivers and people came there but probably not from very far away. (Dublin 1994). Then later manufacturing shifted to urban areas and probably attracted people there from greater distances. Thus it appears that the high rates of population increase within New England and the collapse of local production of grain, allowed industry to develop in the context of plentiful and cheap labor.

Individual wealth was not solely a reflection of farm wealth as one might expect in a region where so many were farmers. The greater importance of population density to wealth than to farm values at all levels of canals, probably reflected the commercial opportunities available in densely populated counties.

As to the relative importance of different forms of transportation, Atack et al (2010) estimated that the railroads contributed to $58 \%$ of urban growth in the Midwest but this is not apparent in the Northeast where the centers of population were already in place when railroads came in. In New York State the canals probably had a similar role to railroads in the Midwest. The population of the Albany/Troy/Schenectady complex, where the Erie joined the Hudson River was third in size after New York City and Boston, and there was also a chain of smaller cities along the canal. This is an example of a spatial effect that varied regionally within the United States at the time.

Proximity to large cities (and smaller ones) was critical in determining farm values, as it was also in manufacturing and in wealth. This certainly confirms the focus upon urbanization in theories of individual inequality. But the effect of the cities extended outward more so than today. The maps of the correlated spatial effects in both farming and manufacturing show the emergence of a central corridor that took in those cities as well as other counties along the Hudson/ Champlain waterway. In farming this went way up to northern Vermont. In manufacturing the counties around New York City merged with the center of manufacturing in western Connecticut. These two overlapping hinterlands in the center of our region of study probably reflected the importance of New York City and the Albany conurbation. This central corridor covering both western New England and eastern New York, transcended the dichotomy of poorer soils in New England vs. better soils in New York state and shows how access to markets trumped soil quality. The map of the correlated spatial effects for wealth did not, however, have such a pattern.

There were, therefore, economic zones very like Von Thunen rings or the core/ periphery distinction of Wallerstein. In this case there was not a single center but, instead, a central zone which we have represented in Map 13. The core consisted of southern New England plus a small bit of New Hampshire where there were textile mills, plus the counties along the two major waterways. The semi periphery consisted of the middle value farm areas, away from the major waterways and industry: southern Vermont and southern New Hampshireand in New York along minor canals. The periphery included: areas in Maine away from the coast, northern New Hampshire and Vermont, areas where a large proportion of the total wealth in a county was in farms, and finally there were the marginal areas where farming was impossible: the Adirondacks, northern Maine, and some counties in northern Pennsylvania. Coastal Maine is difficult to categorize: we put the southern part with southern New Hampshire and Vermont and the northern with the Adirondacks.

How would individual inequality in wealth be related to these zones of absolute levels of wealth created from county-level data? Given Kuznets' original thesis of rising inequality during the early stages of urbanization and industrialization, we expect that inequality will be highest in the areas of highest wealth, in the core areas in Map 13. Inequality should be less among farmers than non-farmers despite the differences between regions we have documented simply because there is a threshold of wealth required to farm at 
all. To be sure there were some farm laborers who did not own their own farms who were much less wealthy than those who did but they were not a large group in this era of family farming. If farmers on poor soils left farming in the areas where manufacturing was growing then this should have produced less inequality among farmers.

If it could be demonstrated that individuals who later earned the highest wages outside of agriculture were raised on farms that were worth more, then rural inequality would feed urban inequality. This might occur if migrants to cities came from close by where farms were more valuable. Also if people from poor farms on poor soils in New England were more apt to leave farming while those from more valuable farms were able to pioneer in the Midwest, where farms were worth more than in New England, again inequalities originating within agriculture would be perpetuated outside. These are some of the hypotheses we will pursue at the individual level.

\section{B. The Persistence of Spatial Inequality}

Labao and Hooks call attention to how history is embedded in places, resulting in the "potential for ...cumulative, uneven development across places(2007: 48)" Meyer had suggested that the existence of higher quality soils continued to affect the economy in New York State long after it lost its grain market to the much more productive soils of the Middle West. Farmers in New York were more able to switch into farm products such as cheese or sheep. Although it is clear there was more to wealth in the farm sector than soil, our analyses confirm that soils had a long temporal reach. Also, as we have seen, manufacturing was able to locate in the more densely populated counties along its canals, perhaps another example of how surplus farm population fueled industrialization. In New England, however, it was poor soils that led to a labor force that was able to work in manufacturing.

Labao and Hooks mapped income by county from 1969 to 1999 and concluded that, while there were some changes, "Most counties retain relative rankings over time, reflecting deeply rooted trends" ( $p$ 31) Peters found that the most important predictor of income inequality for counties in the US Midwest in 2009 was inequality 30 years earlier (2012). Glassmeir (2005) mapped poverty and per capita income in the US from 1960 to 2000. These contemporary studies show that the urban areas and the manufacturing core of New England continue to be wealthy areas. The Erie Canal is longer used but the counties with the cities that grew up on it in Western New York are more wealthy than the rest of New York even today. On the other hand, changes in agriculture and the loss of urban markets for farm products, has resulted in many relatively well off rural areas becoming poorer today. The large hinterland of New York City which we see in the $19^{\text {th }}$ century, has all but disappeared in the contemporary maps. Eastern Vermont also is poorer today than it was in the $19^{\text {th }}$ century. The really marginal areas then continue to be poorer today (see also Moller et. al. 2009: Figure 3).

\section{Issues of Scale}

One reason for the significance of random spatial effects is the presence of high degrees of variation in wealth within counties. All three wealth measures would be skewed towards a few individuals with high wealth in a county. Within counties soils varied quite a bit (see Maps 14 and 15) even in New York and this variation might explain some of that variation. Around the major cities in southern New England, soils might have become more important over time as productivity on farms improved and they specialized for urban markets. Towns with poor soils might have turned away from agriculture (Meyer 2003), the children taking up non-farm work, while others on better soils remained in farming. Farther from major cities, the fine grained soil data shows that soils varied the most in exactly the region where manufacturing was most important.

The key to how these county level inequalities affected individual wealth is migration. It has been estimated that a pioneer needed from 
$\$ 1000$ to $\$ 2000$ to survive the first year and get his new farm operational. If so, the poorer farmers would be the ones to go into manufacturing and the more wealthy would be able to leave the region altogether.For an earlier period we have shown that it was the middle group in our genealogical sample who moved and pioneered new areas (Adams and Kasakoff 1985). In this case, the reach of soils might be even longer. Men who had left farming (and their descendants) were less wealthy simply because they no longer owned farms. So the location of manufacturing in areas where farms had low value would have limited the options of people who were displaced. Only the wealthiest could have afforded to pioneer on farms in the newer areas. Some could have benefitted by acquiring the skills Williamson thought created inequality during economic growth. But those who could not would probably end up with less wealth than if they could have remained in farming.

\section{Conclusions}

This study illustrates the usefulness of Bayesian spatial analysis for understanding how the economy of the $19^{\text {th }}$ century was organized in space. The spatial distribution of soils, transportation and population affected wealth even in an age and region that was certainly more egalitarian and had greater social and geographical mobility than ours today. The methods of spatial analysis have shown that the economy of the Northeast was greatly influenced by transportation networks and access to urban markets but soil quality was also important. The Northeast was dividing into large zones with a central corridor focused upon the Hudson/Champlain waterway, which included the hinterland of the largest city, over and above the spatial factors in our models. Some of these effects have largely disappeared but others relating to the growth of cities and industrialization have remained.

Much work remains to be done to study the limits to equality and the extent to which they can be overcome. Soils represent one of those constraints at least in the $19^{\text {th }}$ century. Our analysis at the county level shows a definite relationship between farm values and the top three classes of soil quality as measured by the Land Capability Classification, a relationship which could also be seen in the more general measure of county -average individual wealth. These relationships are strong enough that we think the soils of today are not very different from those of 1860 , at least when aggregated at the county level. This is not surprising since so much of this classification depends upon slope and drainage. While chemical measures of soil quality might reveal reasons for differences in productivity between farms (e.g. Atack and Bateman 1987), even these simple measures are useful and should be used more widely by historians and social scientists.

In an attempt to measure inequality in preindustrial societies, Milanovicet. al. (2011) have computed a new measure, the inequality possibility frontier. This measures the amount of inequality that could exist over and above providing subsistence incomes to the lowest classes. It is essentially a measure of the social limits to inequality, recognizing that in order to exploit people, the ruling classes need to provide enough to the lower classes so that can continue to live. But there are also limits to equality arising from natural endowments and the spatial structure of the economy. The analysis we have presented is from a time when inequalities, such as soils and access to markets, were perhaps more important than they are today when it is education which many think drives inequality. Yet, as the studies of contemporary poverty and inequality show, spatial inequalities are still quite evident in the United States, many of them deeply rooted in the past. Recently evidence from developing countries has shown that global inequality has increased over time but largely due to differences among countries rather than to changes in distribution of incomes within countries (Ferreira and Ravillon 2009: 619). The roles of different countries in a system of international trade isanalogous to the counties within the region of the US that we have analyzed here. These examples show the continuing importance of spatial inequality at different scales today. 


\section{Acknowledgments}

There are so many people who have contributed to this project from its beginning. Here I will acknowledge those who helped with this latest round. Ken Sylvester suggested we use the Land Capability Classification and shared a tool that facilitated downloading it from the USDA Website. Alan Rickenbaker did the downloading and compiled the soil data. Bin Feng made many of the soil maps used in this article and others we have not included. We would like to thank Jeremy Atack for sharing his codes for transportation. Lee Craig also helped by making his transportation codes available and he and Tom Weiss also provided estimates of the labor force in agriculture. We would like to acknowledge the National Historic GIS for providing the data from the census. We would like to acknowledge two grants from the Demographic and Behavioral Sciences Branch of the National Institute of Child Health and Human Development, National Institutes of Health which have supported this research: "Modeling Spatial and Family Factors in the Transmission of Wealth" (Grant \#R21HDo6011102), our current grant and an earlier grant "Migration and Intergenerational Processes" (with John W. Adams).

\section{Endnotes}

1. The transportation variables were provided by Atack from his more recent work and differed somewhat from similar variables available from NHGIS provided by Craig. We further coded the following counties as having major canals, all were in New York: Oswego, Herkimer, Wayne, Schenectady, Monroe, Seneca, Erie, Washington, Ontario, Cayuga, Onondaga, Niagara, Orleans, Rensselaer, Warren, Madison, Montgomery, Oneida and Saratoga. Warren County had been coded as not having a canal in 1860 by Atack but since the canal passed through a tiny corner of it, we decided to include it. We classified the following counties as having minor canals: Rutland, VT, Cumberland, ME, the following counties in NY: Schulyer, Chenango, Lewis, Ulster, Broome, Livingston, Chemung, Steuben, Jefferson, Wyoming, Dutchess, Cattaraugus, Sullivan, Orange, Tompkins, Yates. Tompkins had been classified by Atack as not having a canal, but since it was at the end of a Finger Lake attached to the Erie system we included it. In Pennsylvania, the following counties had minor canals in our classification: Venango, Lycoming, Luzerne, Wayne, Mercer, Union, Wyoming, Clinton, Crawford, Erie, Monroe, Pike and Bradford.

\section{References}

Adams JW and Kasakoff AB ,1985, Wealth and migration in Massachusetts and Maine: 1771-1798,The Journal of Economic History, volume 45, 363-368.

Atack J and Bateman F,1987,To Their Own Soil: Agriculture in the Antebellum North, Ames: Iowa State University Press.

Atack J, Bateman FandParker WN, 2000, The Farm, the Farmer and the Market,The Cambridge Economic History of the United States, edited by Engerman, Sand Gallman, R,Cambridge: Cambridge University Press,volume 2, pages 245-284.

Atack J, Bateman F, Haines M and Margo RA,2010, Did Railroads Induce or Follow Economic Growth? Urbanization and Population Growth in the American Midwest, 1850-1860,Social Science History, volume34, pages 171-197.

Benirschka M and Binkley JW, 1994, Land price volatility in a geographically dispersedmarket, American Journalof Agricultural Economics, volume 76 , pages $185-195$.

Clark VS, 1929,History of Manufactures in the United States 1607-1860, Carnegie Institution of Washington, volume 1.

Curtis, Katherine, Paul R. Voss and David D. Long 2012 Spatial variation in poverty-generating processes: Child poverty in the United States Social Science Research 41: 146-159.

Dublin, T. , 1994,Transforming Women's Work: New England Lives during the Industrial Revolution, Ithaca, N.Y, Cornell University Press.

Engerman S and Sokoloff K,2000, Technology and Industrialization, The Cambridge Economic History 
of the United States, edited by Engermans and Gallman R,Cambridge: Cambridge University Press,volume 2, pages 367-402.

Ferriera F and Ravallon M,2009, Poverty and Inequality: The Global Context,The Oxford Handbook of Economic Inequality, edited by Wiemer S, Nolan B and Smeeding T, Oxford: Oxford University Press, pages 699-636.

Field A, 1978, Sectoral Shift in Antebellum Massachusetts: A Reconsideration, Explorations in Economic History, volume 15, pages 378-401.

Fishlow A, 2000, Internal Transportation in the Nineteenth and Early Twentieth Centuries, The Cambridge Economic History of the United States, edited by EngermanS and Gallman R, Cambridge: Cambridge University Press,volume 2, pages 543-642.

Foster DR and Aber JD, 2004,Forests in Time: The Environmental Consequences of 1,00o of Change in New England, New Haven: Yale University Press.

Gelman A, 2006, Prior distributions for Variance parameters in Hierarchical Models, Bayesian Analysis, volume 1, pages 515- 533.

Glasmeir, A K. 2005 An Atlas of Poverty in America: One Nation, Pulling Apart, 1960-2003. New York, NY. : Routledge.

Goldin CD and Sokoloff KL, 1985, The Relative Productivity Hypothesis of Industrialization: The American Case, 1820 to 1850,Quarterly Journal of Economics, volume 99, pages 461-87.

Helms D, 1992, The Development of the Land Capability Classification, Readings in the History of the Soil Conservation Service, Washington, D.C: Soil Conservation Service, pages 60-73. (www.nrcs.usda.gov/about/history/articles/

landclassification.html)

HockensmithRD, 1948, The Use of the LandCapability Maps for Rural Real Estate Assessments, Proceedings of the Forty-First Annual Conference on Taxation, sponsored by TheNational Tax Association.

Kearl JR and Pope CL, 1984, Mobility and Distribution, The Review of Economics and Statistics, volume 66, pages 192-199.

Kearl JR and Pope CL, 1986a, Choices, rents and luck: economic mobility of nineteenth-century Utah households, Long-Term Factors in American Economic Growth, edited by Engerman $\mathrm{S}$ and Gallman R, Chicago: University of Chicago Press, pages 215-26o.
Kearl JR and Pope CL , 1986b, Unobservable family and individual contributions to the distributions of income and wealth, Journal of Labor Economics, volume 4, pages S48-S79.

KuznetsS, 1955,Economic Growth and Income Inequality, The American Economic Review, volume 45, pages 1-28.

Labao, Linda M. , Gregory Hooks and Ann R. Tickamyer, eds. 2007 The Sociology of Spatial Inequality. Albany: State University of New York Press

Labao, Linda M. and Gregory Hooks 2007 "Advancing the Sociology of Spatial Inequality: Spaces, Places, and the Subnational Scale" in Labao, Linda M. , Gregory Hooks and Ann R.

Lawson,A. B.2009 Bayesian Disease Mapping: hierarchical modeling in Spatial Epidemiology. CRC Press, New York.

Lawson, A. B. and S. Banerjee 2010Bayesian Spatial Analysis ch 17 in The Handbook of Spatial Analysis. Fotheringham, S. and Rogerson, P. (eds) Sage, New York

Lesaffre,E. and Lawson, A. B. 2012 Bayesian Biostatistics. Wiley, New York

Tickamyer , eds. 2007 The Sociology of Spatial Inequality. Albany: State University of New York Press, pp. $29-62$.

MargoR, 2000,Wages and Labor Markets in the United States, 1820-1860, Chicago: The University of Chicago Press.

Mathews, LK, 1962,The Expansion of New England: The Spread of New England Settlement and Institutions to the Mississippi River, 1620-1865,New York: Russell and Russell.

Mazumder B ,2005, Fortunate Sons: New Estimates of Intergenerational Mobility in the United States Using Social Security Earnings Data,The Review of Economics and Statistics, volume 87,pages 235-255.

Meinig D, 1993,The Shaping of America: a Geographic Perspective on 500 Years of History, New Haven: Yale University Press, volume 2: Continental America, 1800 - 1867.

Meyer D, 2003, The Roots of American Industrialization, Baltimore: The Johns Hopkins University Press. 
MilanovicB,Lindert PH and Williamson JG, 2011, PreIndustrial Inequality, The Economic Journal, volume 121, pages 255-272.

Minnesota Population Center, 2011,National Historical Geographic Information System: Version 2.o. Minneapolis, MN: University of Minnesota. http://www.nhgis.org

Moller, Stephanie, Arthur S. Alderson and Francois Nielsen 2009 , Changing Patterns of Income Inequality in U.S. Counties American Journal of Sociology 114 (4):1037-1101.

ParkersonD, 1995, The Agricultural Transition in New York State: Markets and Migration in midnineteenth Century America, Ames: Iowa State University Press.

Peters, David J. 2012 Income Inequality across Micro and Meso Geographic Scales in the Midwestern United States, 1979-2009 Rural Sociology 77 (2):171-202.

Plantigna AJ, 1996,The Effect of Agricultural Policies on Land Use and Environmental Quality,American Journal of Agricultural Economics,volume 78, pages 1082-1091.

Pope C, 2000, Inequality in the Nineteenth Century,The Cambridge Economic History of the United States, edited by Engerman SL and Gallman R, Cambridge: Cambridge University Press,volume 2, pages 109-142.

Soil Survey Staff, Natural Resources Conservation Service, United States Department of Agriculture. Soil Survey Geographic (SSURGO) Database for Connecticut (Accessed 11/22/2009, 8/9/2010), Maine (Accessed 10/26/2009, 11/23/2009) Massachusetts (Accessed 11/30/2009, 1/6/2010), New Hampshire, (Accessed 11/17/2009) New York (Accessed 11/17/2009), Pennsylvania (Accessed 11/17/2009) Rhode Island (Accessed 11/22/2009) and Vermont. (Accessed 10.26.2009) Available online at http://soildatamart.nrcs.usda.gov.

Solon G, 1992, Integrational income mobility in the United States, American Economic Review, volume 82, pages 393-408.

Solon G, 1999, Intergenerational mobility in the labor market, Handbook of Labor Economics, edited by Ashenfelter OC and Card D, Amsterdam: North Holland, volume 3, pages 1761-18oo.

Solon G, 2002, Cross-country differences in intergenerational earnings mobility, Journal of Economic Perspectives, volume 16, pages 59-66.

Steckel RH and Moehling CM, 2001, Rising inequality: trends in the distribution of wealth in industrializing New England, Journal of Economic History, volume 61, pages 160-183.

U.S. Bureau of the Census, Eighth Decennial Census of the United States, 1860. 1864a,

Population of the United States in 1860 , Washington, D.C.: Government Printing Office.

U.S. Bureau of the Census, Eighth Decennial Census of the United States, 1860, 1864b,

Agriculture of the United States in 1860, Washington, D.C.: Government Printing Office.

U.S. Bureau of the Census, Eighth Decennial Census of the United States, 1860, 1866, Statistics of the United States (including Mortality, Property, etc.) in 1860, Washington, D.C.: Government Printing Office.

U.S. Bureau of the Census, Geographic Reference Manual, 2012, www.census.gov/geo/www/GARM/ Ch12GARM.pdf

WilliamsonJG, 1991,Inequality, poverty, and history, New Haven: Yale University Press.

Williamson JG and Lindert PH, 1980, American Inequality: A Macroeconomic History, New York: Academic Press.

\section{Declaration of Conflicting Interests}

The authors declared no potential conflicts of interest with respect to the research, authorship, and/or publication of this article. 


\section{Appendix One: The Land Capability Classification}

that make them unsuited to cultivation and that restrict their use mainly to grazing, forestland, or wildlife.
Figure 1: Land Capability Classes

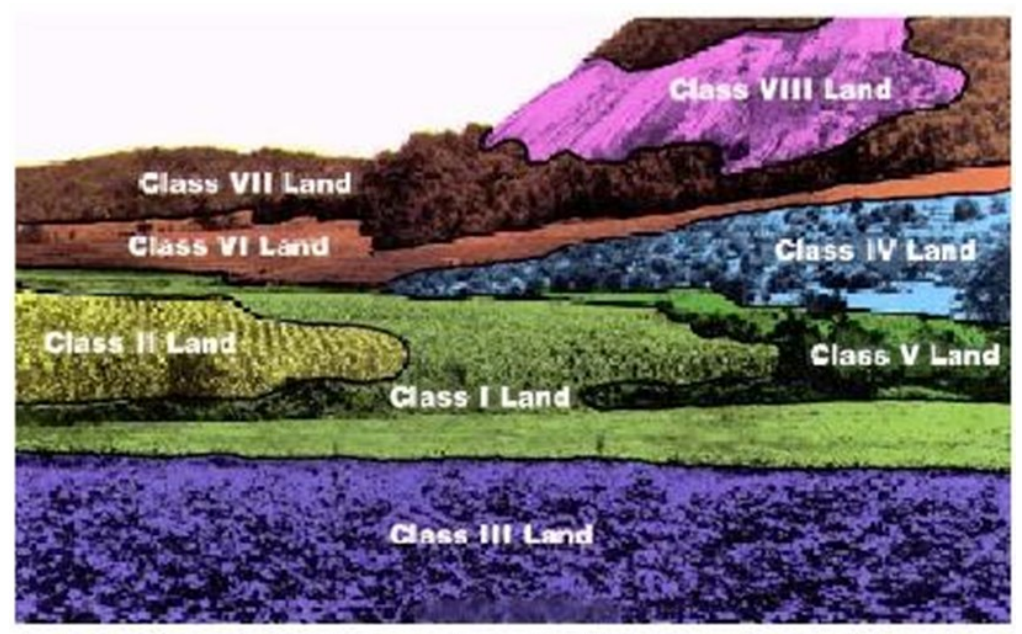

Landscapes with land capability classes outlined.

\section{Classes and definitions.}

Class I (1) soils have slight limitations that restrict their use.

Class II (2) soils have moderate limitations that reduce the choice of plants or require moderate conservation practices.

Class III (3) soils have severe limitations that reduce the choice of plants or require special conservation practices, or both.

Class IV (4) soils have very severe limitations that restrict the choice of plants or require very careful management, or both.

Class $V$ (5) soils have little or no hazard of erosion but have other limitations, impractical to remove, that limit their use mainly to pasture, range, forestland, or wildlife food and cover.

Class VI (6) soils have severe limitations that make them generally unsuited to cultivation and that limit their use mainly to pasture, range, forestland, or wildlife food and cover.

Class VII (7) soils have very severe limitations
Class VIII (8) soils and miscellaneous areas have limitations that preclude their use for commercial plant production and limit their use to recreation, wildlife, or water supply or for esthetic purposes.

Source for above: http://soils.usda.gov/ technical/handbook/contents/part622.h $\underline{t m l}$

The Soil Conservation Service sent teams of men into the field to make the surveys both before and after WWII. In 1950, for example, there were 700 surveyors working on this project. (Helms 1992: 9) The survey is extremely detailed because it was designed to advise farmers which crops to plant in particular fields. Here we see how detailed it was and also how varied the soils were in most of New England.

The land capability classification is available in great detail. Not only was the quality of soil lower in general in New England than in New York (compare Maps 2 and 3), soils were also much more variable there. The "patch size" is larger in New York than it was in New England. But even so, the soils in each township were different: there was, in both counties, a gradient from East to West (compare Maps 14 and 15).

We compared the area included in the land capability classification with the area in the 1860 county using GIS. Table 2 lists the counties with less than $80 \%$ coverage. Many were forested areas at the margins of agriculture and others were sites of major cities. There were also a few rural counties for which we could find no data. Those with very little data were omitted from our spatial analysis. 
Table 6: Counties with less than $80 \%$ coverage in the Land Capability Classification

\begin{tabular}{|c|c|}
\hline County & Proportion GIS area classified \\
\hline \multicolumn{2}{|l|}{ Maine } \\
\hline Pisquataquis & $24 \%$ \\
\hline Aroostock & $58 \%$ \\
\hline Somerset & $72 \%$ \\
\hline \multicolumn{2}{|l|}{ Massachusetts } \\
\hline Suffolk (City of Boston) & Not included, no soils available \\
\hline Franklin & Not included, no soils available \\
\hline Essex & $67 \%$ \\
\hline Worcester & $72 \%$ \\
\hline Nantucket & $74 \%$ \\
\hline \multicolumn{2}{|l|}{ New Hampshire } \\
\hline Carroll & $69 \%$ \\
\hline Grafton & $68 \%$ \\
\hline Coos & $54 \%$ \\
\hline \multicolumn{2}{|l|}{ New York } \\
\hline Franklin & $29 \%$ \\
\hline Herkimer & $36 \%$ \\
\hline Lewis & $57 \%$ \\
\hline New York (New York City) & Not included, no soils available \\
\hline Queens & $27 \%$ \\
\hline Westchester & $67 \%$ \\
\hline \multicolumn{2}{|l|}{ Pennsylvania } \\
\hline Allegany & $78 \%$ \\
\hline \multicolumn{2}{|l|}{ Vermont } \\
\hline Grand Isle & $42 \%$ \\
\hline Essex & Not included, no soils available \\
\hline
\end{tabular}




\section{Appendix Two: Models and DIC}

Table 7. DIC and pD table for wealth, farm value per acre and manufacturing per capita with all interaction terms and log of distance to the closest big city

\begin{tabular}{|c|c|c|c|c|c|c|}
\hline $\begin{array}{l}\text { Non-log } \\
\text { Models (y) }\end{array}$ & Models without v[i] and w[i] & Dbar & SD & pD & $\begin{array}{l}\text { DIC } \\
\text { manual* }\end{array}$ & $\begin{array}{l}\text { DIC from } \\
\text { winbugs }\end{array}$ \\
\hline $\begin{array}{l}\mathrm{y}=\text { wealth per } \\
\text { capita }\end{array}$ & $\begin{array}{l}\text { y[i] dnorm(mu[i],tauy) } \\
\text { a0+a1*x1c[i]+a2*x2c[i]+a3*x3c[i] } \\
\text { +a4*x4c[i]+a5*x5c[i]+a6*logx6c[i] } \\
\text { +Pfac[port2[i]]+Cfac[canal2[i]] } \\
\text { +Rfac[river2[i]]+RRfac[rr2[i]] } \\
\text { +Cfac2[canal2[i]]*x2[i] } \\
\text { +Cfac3[canal2[i]]*x3[i] } \\
\text { +Cfac4[canal2[i]]*x4[i] } \\
\text { +Cfac5[canal2[i]]*x5[i] }\end{array}$ & 415600.0 & 218.8 & 23936.72 & 439536.72 & 415639.0 \\
\hline \begin{tabular}{|l} 
Farm value per \\
acre
\end{tabular} & $\begin{array}{l}\text { y[i] dnorm(mu[i],tauy) } \\
\text { a0+aa1*x1c[i]+a2*x2c[i]+a3*x3c[i] } \\
\text { +a4*x4c[i]+a5*x5c[i]+a6*logx6c[i] } \\
\text { +Pfac[port2[i]]+Cfac[canal2[i]] } \\
\text { +Rfac[river2[i]]+RRfac[rr2[i]] } \\
\text { +Cfac2[canal2[i]]*x2[i] } \\
\text { +Cfac3[canal2[i]]*x3[i] } \\
\text { +Cfac4[canal2[i]]*x4[i] } \\
\text { +Cfac5[canal2[i]]*x5[i] }\end{array}$ & 3860.0 & 22.04 & 242.88 & 4102.88 & 3874.18 \\
\hline \begin{tabular}{|l|} 
Manufacturing \\
capital per capita
\end{tabular} & $\begin{array}{l}\text { y[i] dnorm(mu[i],tauy) } \\
\text { a0+a1*x1c[i]+a2*x2c[i]+a3*x3c[i] } \\
\text { +a4*x4c[i]+a5*x5c[i]+a6*logx6c[i] } \\
\text { +Pfac[port2[i]]+Cfac[canal2[i]] } \\
\text { +Rfac[river2[i]]+RRfac[rr2[i]] } \\
\text { +Cfac2[canal2[i]]*x2[i] } \\
\text { +Cfac3[canal2[i]]*x3[i] } \\
\text { +Cfac4[canal2[i]]*x4[i] } \\
\text { +Cfac5[canal2[i]]*x5[i] }\end{array}$ & 134200.0 & 99.39 & 4939.19 & 139139.19 & 134233.0 \\
\hline
\end{tabular}




\begin{tabular}{|c|c|c|c|c|c|c|}
\hline \begin{tabular}{|l} 
Non-log \\
Models (y)
\end{tabular} & Models with v[i] & Dbar & SD & $\mathrm{pD}$ & $\begin{array}{l}\text { DIC } \\
\text { manual }\end{array}$ & $\begin{array}{l}\text { DIC from } \\
\text { winbugs }\end{array}$ \\
\hline $\begin{array}{l}\mathrm{y}=\text { wealth per } \\
\text { capita }\end{array}$ & $\begin{array}{l}\text { y[i] dnorm(mu[i],tauy) } \\
\text { a0+a1*x1c[i]+a2*x2c[i]+a3*x3c[i] } \\
\text { +a4*x4c[i]+a5*x5c[i]+a6*logx6c[i] } \\
\text { +Pfac[port2[i]]+Cfac[canal2[i]] } \\
\text { +Rfac[river2[i]]+RRfac[rr2[i]] } \\
\text { +Cfac2[canal2[i]]*x2[i] } \\
\text { +Cfac3[canal2[i]]*x3[i] } \\
\text { +Cfac4[canal2[i]]*x4[i] } \\
\text { +Cfac5[canal2[i]]*x5[i] ]+v[i] }\end{array}$ & 109800.0 & 479.2 & 114816.32 & 224616.32 & 109924.0 \\
\hline $\begin{array}{l}\text { Y=Farm value } \\
\text { per acre }\end{array}$ & $\begin{array}{l}\text { y[i] dnorm(mu[i],tauy) } \\
\text { a0+a1*x1c[i]+a2*x2c[i]+a3*x3c[i] } \\
\text { +a4*x4c[i]+a5*x5c[i]+a6*logx6c[i] } \\
\text { +Pfac[port2[i]]+Cfac[canal2[i]] } \\
\text { +Rfac[river2[i]]+RRfac[rr2[i]] } \\
\text { +Cfac2[canal2[i]]*x2[i] } \\
\text { +Cfac3[canal2[i]]*x3[i] } \\
\text { +Cfac4[canal2[i]]*x4[i] } \\
\text { +Cfac5[canal2[i]]*x5[i] ]+v[i] }\end{array}$ & 1443.0 & 44.74 & 1000.83 & 2443.83 & 1521.22 \\
\hline $\begin{array}{l}\text { Y=Manufactur } \\
\text { ing capital per } \\
\text { capita }\end{array}$ & $\begin{array}{l}\text { y[i] dnorm(mu[i],tauy) } \\
\text { a0+a1*x1c[i]+a2*x2c[i]+a3*x3c[i] } \\
\text { +a4*x4c[i]+a5*x5c[i]+a6*logx6c[i] } \\
\text { +Pfac[port2[i]]+Cfac[canal2[i]] } \\
\text { +Rfac[river2[i]]+RRfac[rr2[i]] } \\
\text { +Cfac2[canal2[i]]*x2[i] } \\
\text { +Cfac3[canal2[i]]*x3[i] } \\
\text { +Cfac4[canal2[i]]*x4[i] } \\
\text { +Cfac5[canal2[i]]*x5[i]+v[i] }\end{array}$ & $\overline{35010.0}$ & 267.6 & 35804.88 & 70814.88 & 35086.6 \\
\hline
\end{tabular}




\begin{tabular}{|c|c|c|c|c|c|c|}
\hline \begin{tabular}{|l|} 
Non-log \\
Models (y)
\end{tabular} & Models with v[i] and w[i] & Dbar & SD & $\mathrm{pD}$ & \begin{tabular}{|l} 
DIC \\
manual
\end{tabular} & $\begin{array}{l}\text { DIC from } \\
\text { winbugs }\end{array}$ \\
\hline $\begin{array}{l}\mathrm{Y}=\text { wealth per } \\
\text { capita }\end{array}$ & $\begin{array}{l}\text { y[i] dnorm(mu[i],tauy) } \\
\text { a0+a1*x1c[i]+a2*x2c[i]+a3*x3c[i] } \\
\text { +a4*x4c[i]+a5*x5c[i]+a6*logx6c[i] } \\
\text { +Pfac[port2[i]]+Cfac[canal2[i]] } \\
\text { +Rfac[river2[i]]+RRfac[rr2[i]] } \\
\text { +Cfac2[canal2[i]]*x2[i] } \\
\text { +Cfac3[canal2[i]]*x3[i] } \\
\text { +Cfac4[canal2[i]]*x4[i] } \\
\text { +Cfac5[canal2[i]]*x5[i]+ v[i]+w[i] }\end{array}$ & 76810.0 & 425.4 & 90482.58 & 167292.58 & 76899.50 \\
\hline $\begin{array}{l}\text { Y=Farm value } \\
\text { per acre }\end{array}$ & $\begin{array}{l}\text { y[i] dnorm(mu[i],tauy) } \\
\text { a0+a1*x1c[i]+a2*x2c[i]+a3*x3c[i] } \\
\text { +a4*x4c[i]+a5*x5c[i]+a6*logx6c[i] } \\
\text { +Pfac[port2[i]]+Cfac[canal2[i]] } \\
\text { +Rfac[river2[i]]+RRfac[rr2[i]] } \\
\text { +Cfac2[canal2[i]]*x2[i] } \\
\text { +Cfac3[canal2[i]]*x3[i] } \\
\text { +Cfac4[canal2[i]]*x4[i] } \\
\text { +Cfac5[canal2[i]]*x5[i]+ v[i]+w[i] }\end{array}$ & 1217.0 & 41.08 & 843.78 & 2060.78 & 1307.97 \\
\hline $\begin{array}{l}\text { Y=Manufacturi } \\
\text { ng capital per } \\
\text { capita }\end{array}$ & $\begin{array}{l}\text { y[i] dnorm(mu[i],tauy) } \\
\text { a0+a1*x1c[i]+a2*x2c[i]+a3*x3c[i] } \\
\text { +a4*x4c[i]+a5*x5c[i]+a6*logx6c[i] } \\
\text { +Pfac[port2[i]]+Cfac[canal2[i]] } \\
\text { +Rfac[river2[i]]+RRfac[rr2[i]] } \\
\text { +Cfac2[canal2[i]]*x2[i] } \\
\text { +Cfac3[canal2[i]]*x3[i] } \\
\text { +Cfac4[canal2[i]]*x4[i] } \\
\text { +Cfac5[canal2[i]]*x5[i]+ v[i]+w[i] }\end{array}$ & 7171.0 & 124.4 & 7737.68 & 14908.68 & 7261.96 \\
\hline
\end{tabular}

*Formula used DIC $=$ Dbar $+\mathrm{SD}^{2} / 2$

\# x1 urban_percent

\#x2 FB_percent

\#x3 population density

$\#$ x5 proportion of good soil

\#x6 log of close distance

\#Pfac port

\# Rfacriver

\#Cfac canal

\#RRfac (rail road)

\#Cfac2 - interaction between canal and foreign born percent

\#Cfac3 - interaction between canal and population density

\#Cfac4 - interaction between canal and improved percent

\#Cfac5 - interaction between canal and proportion good soil 


\section{Appendix Maps}

Map 1. Soils in the Northeastern US

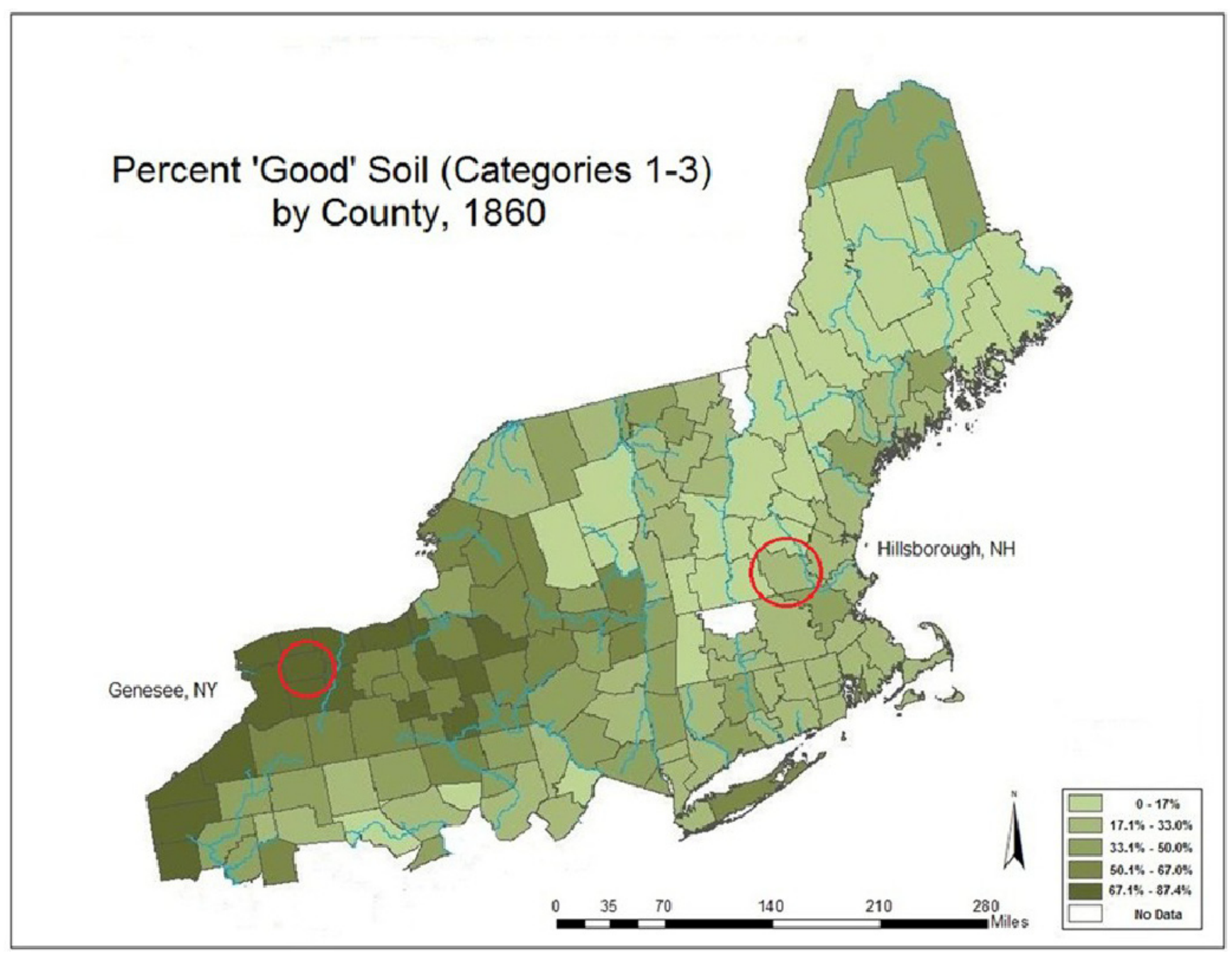


Map 2. Land Capability in Genesee County New York

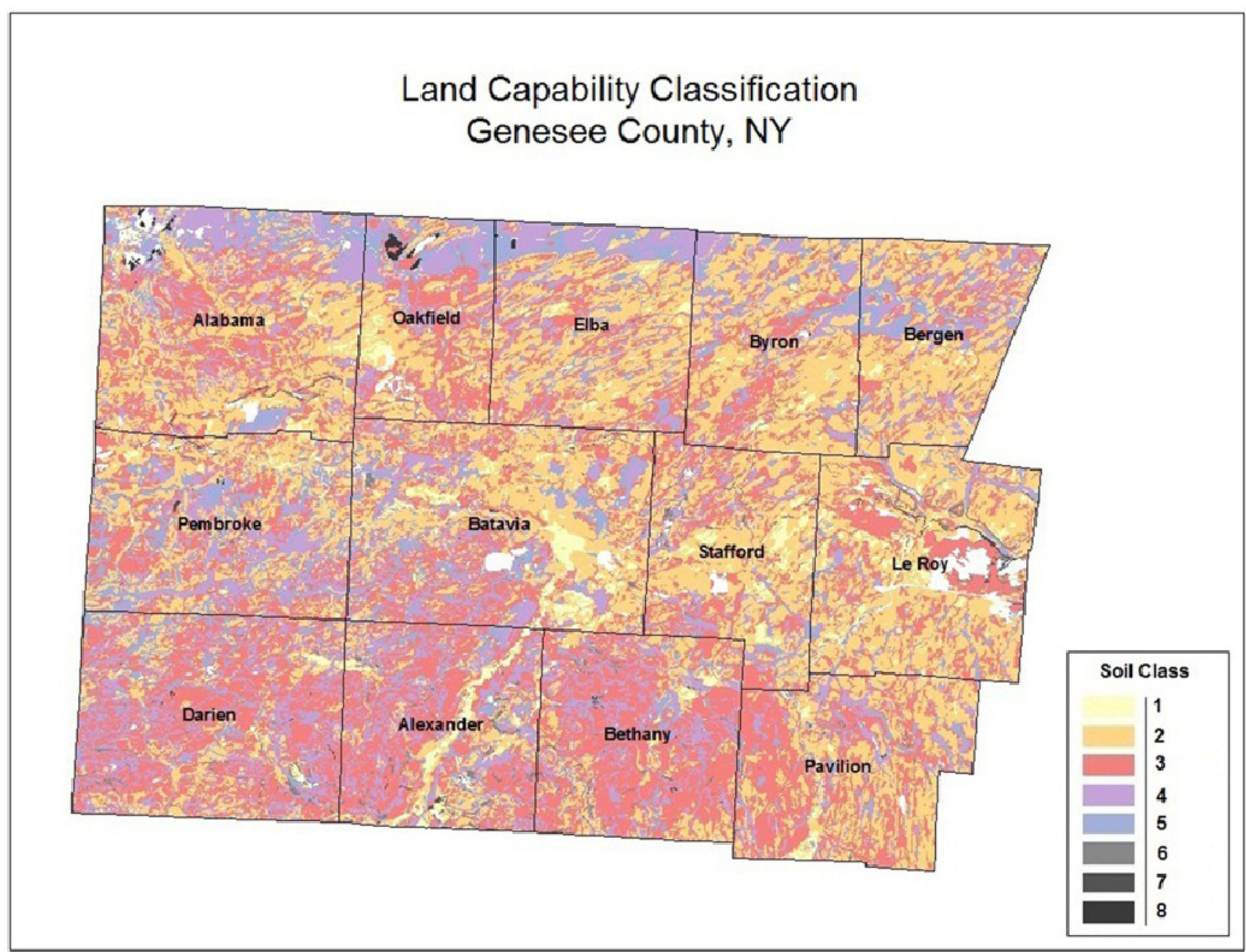


Map 3. Land Capability in Hillsborough County New Hampshire

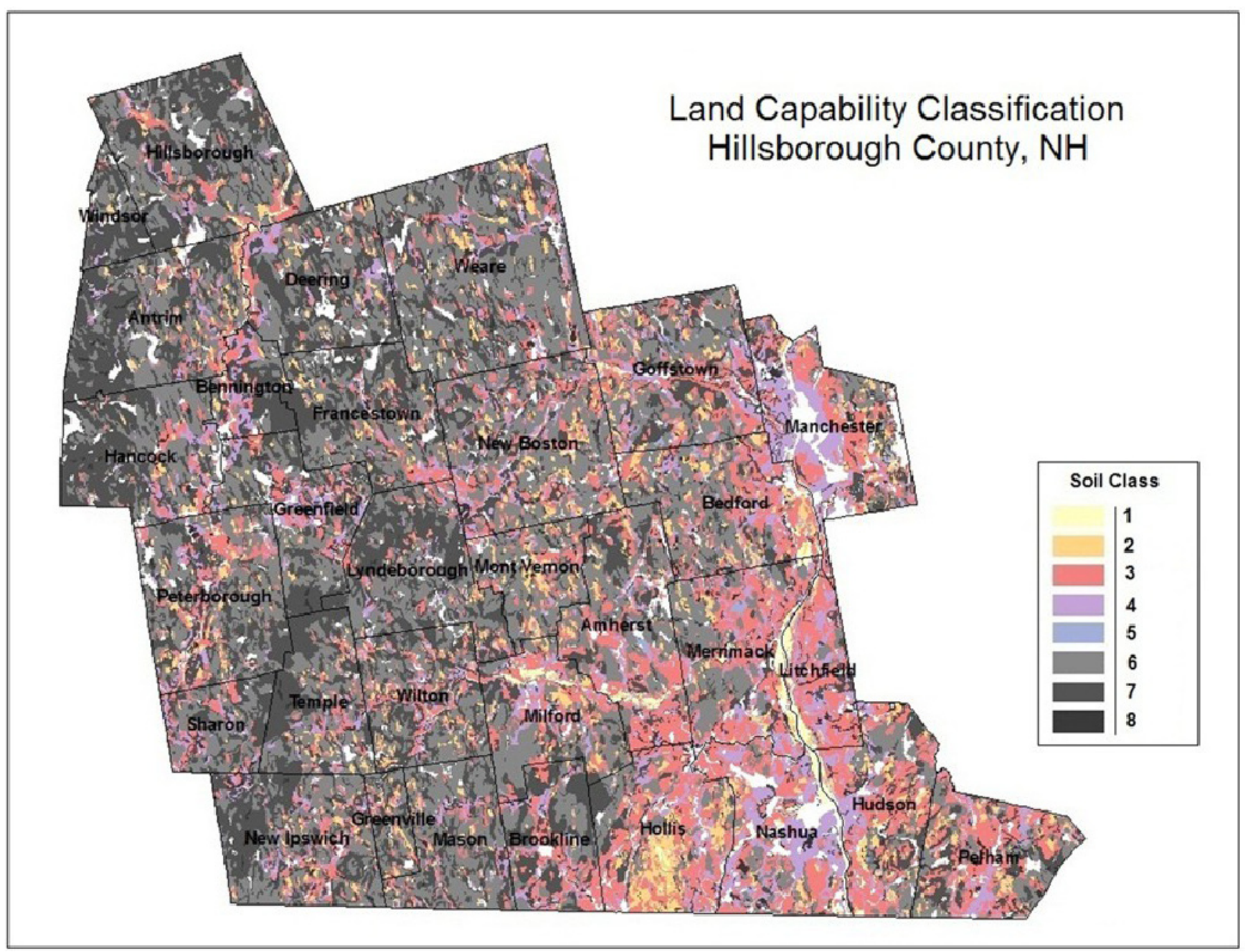


Map 4. Farm Value per Acre, 1860

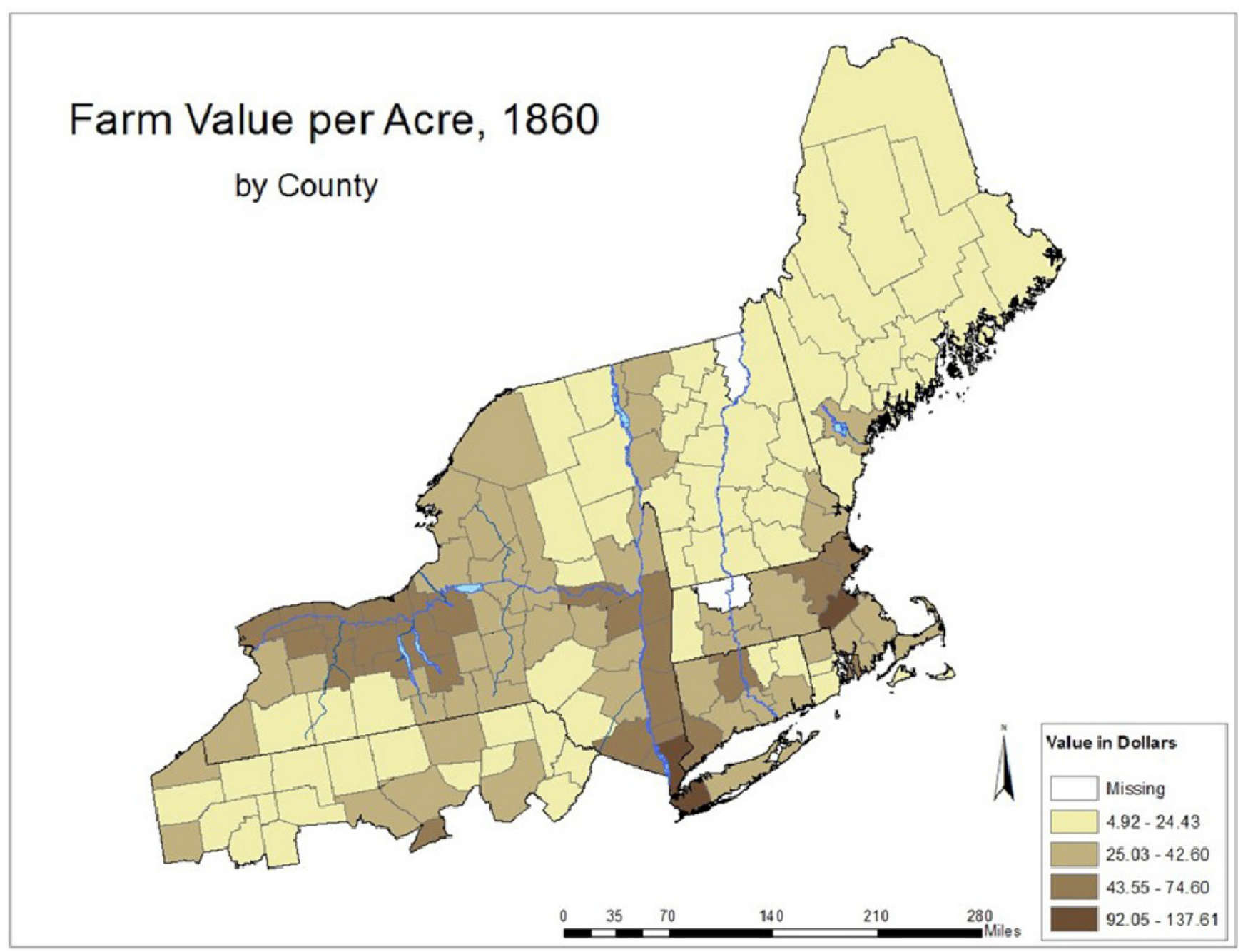


Map 5. Capital Invested in Manufacturing per Capita, 1860

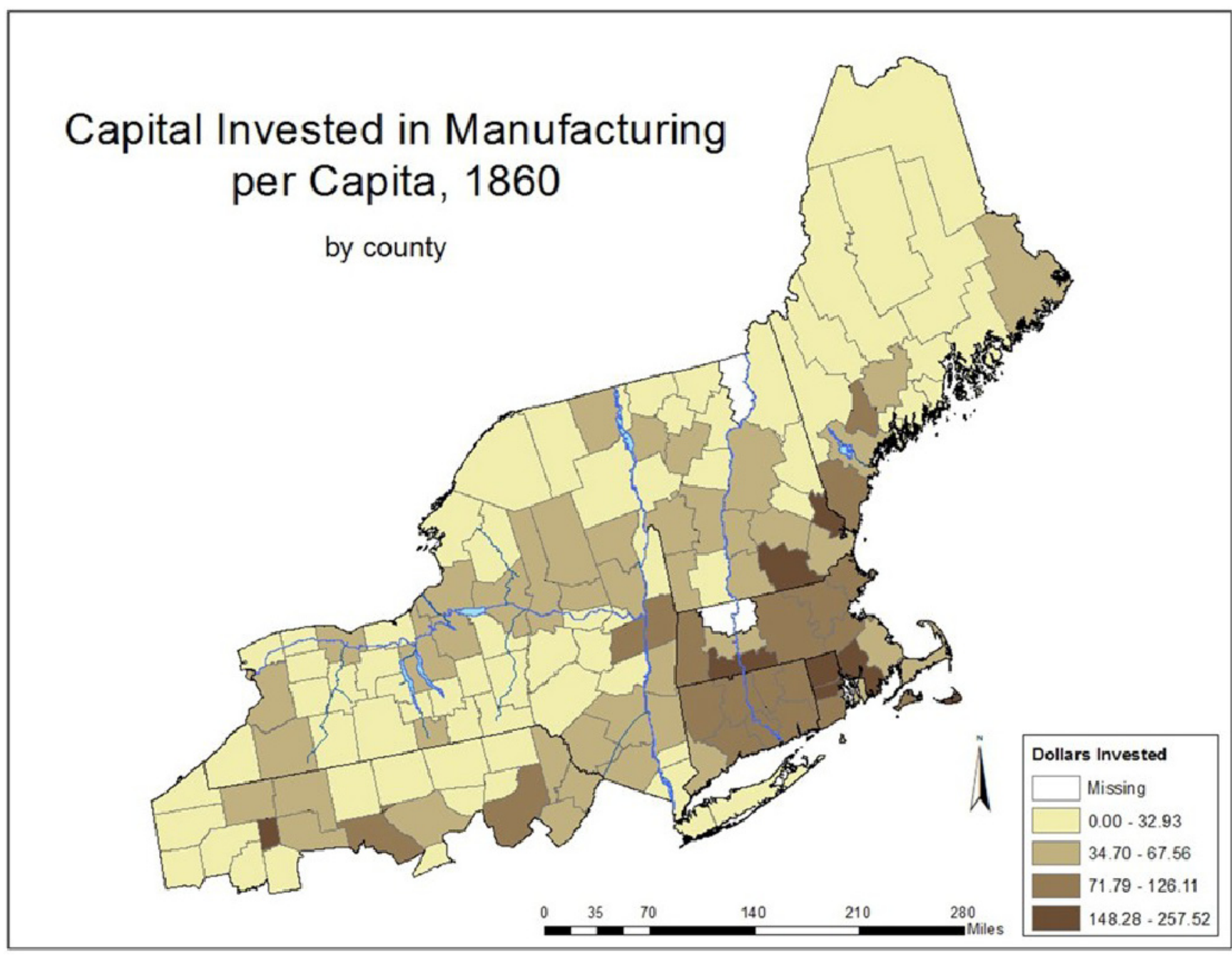


Map 6. County-Average Individual Wealth in 1860

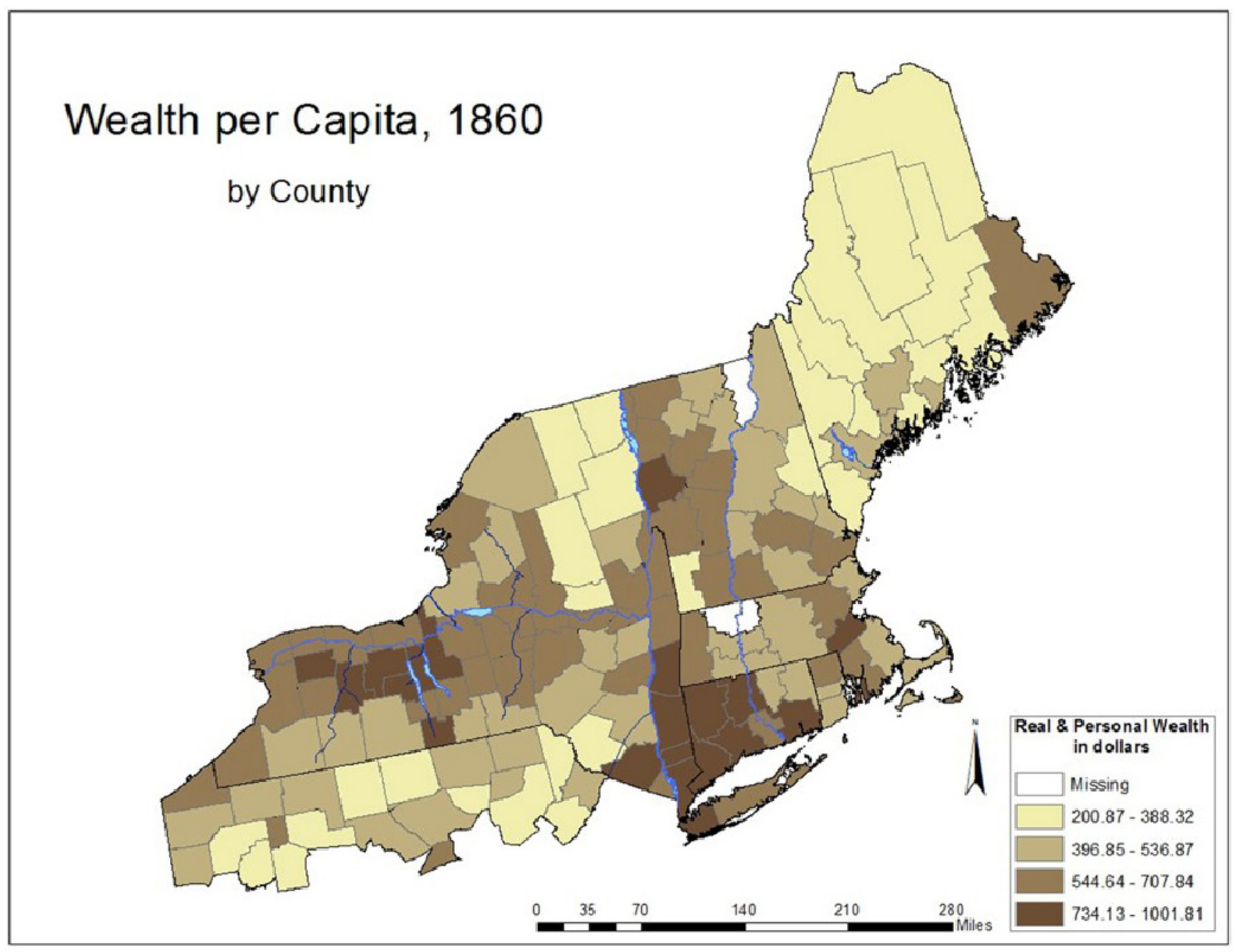


Map 7. Random Spatial Effects from Model of Farm Value per Acre

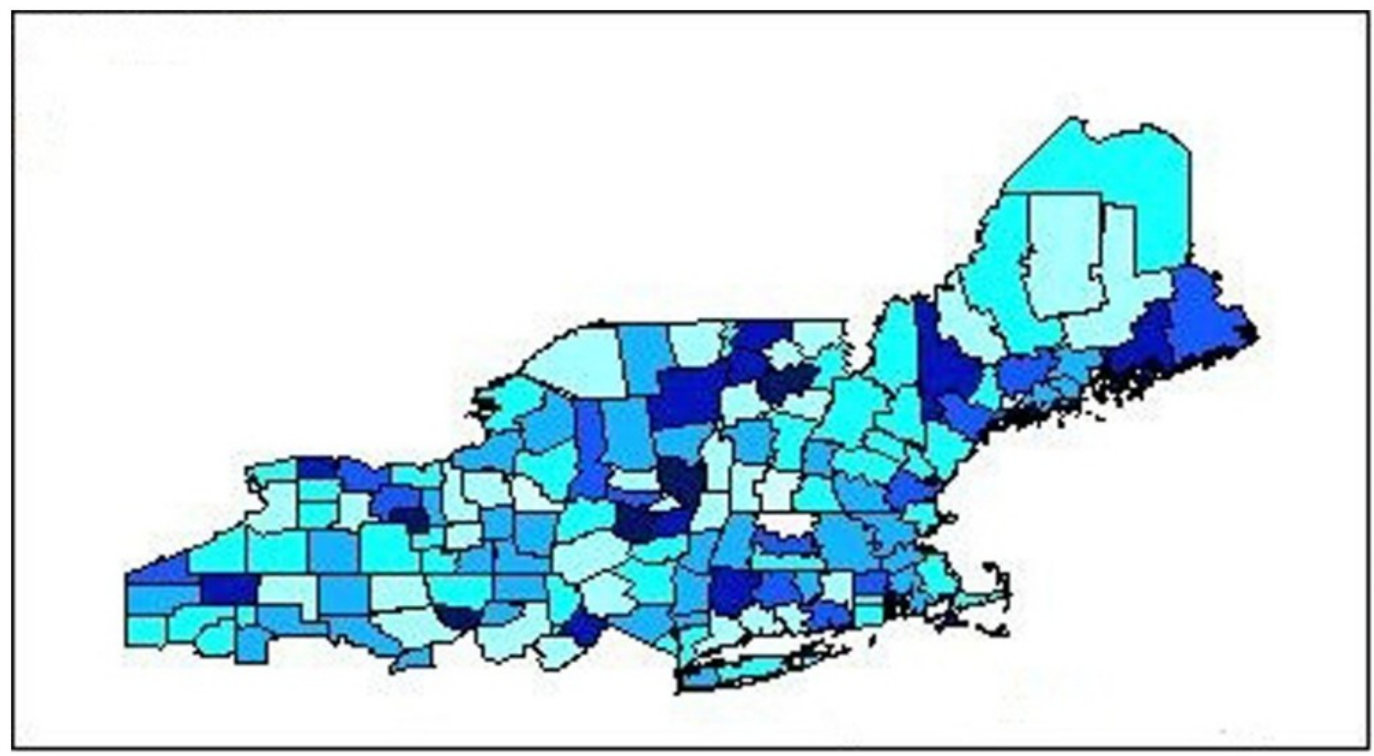

\section{County Means}

less than -10.0

-10.0 to -2.5

-2.5 to 0

0 to 2.5

2.5 to 5.0

5.0 to 7.5

over 7.5

Map 8. Correlated Spatial Effects from Model of Farm Value per Acre

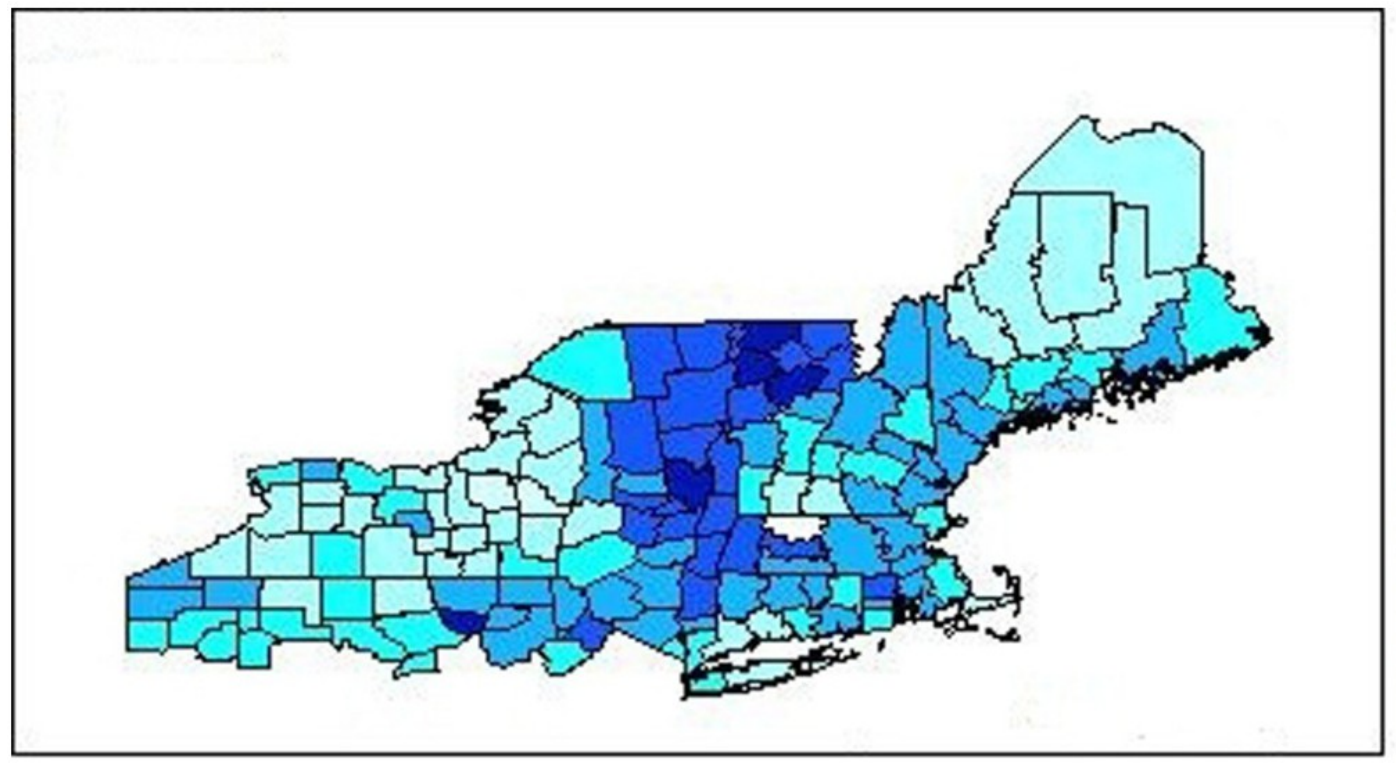

\section{County Means}

less than -5.0

-5.0 to -1.5

-1.5 to 0.0

0.0 to 1.5

1.5 to 5.0

5.0 to 7.5

over 7.5 
Map 9. Random Spatial Effects from Model of Capital Invested in Manufacturing per Capita

Map 10. Correlated Spatial Effects from Model of Capital Invested in Manufacturing per Capita

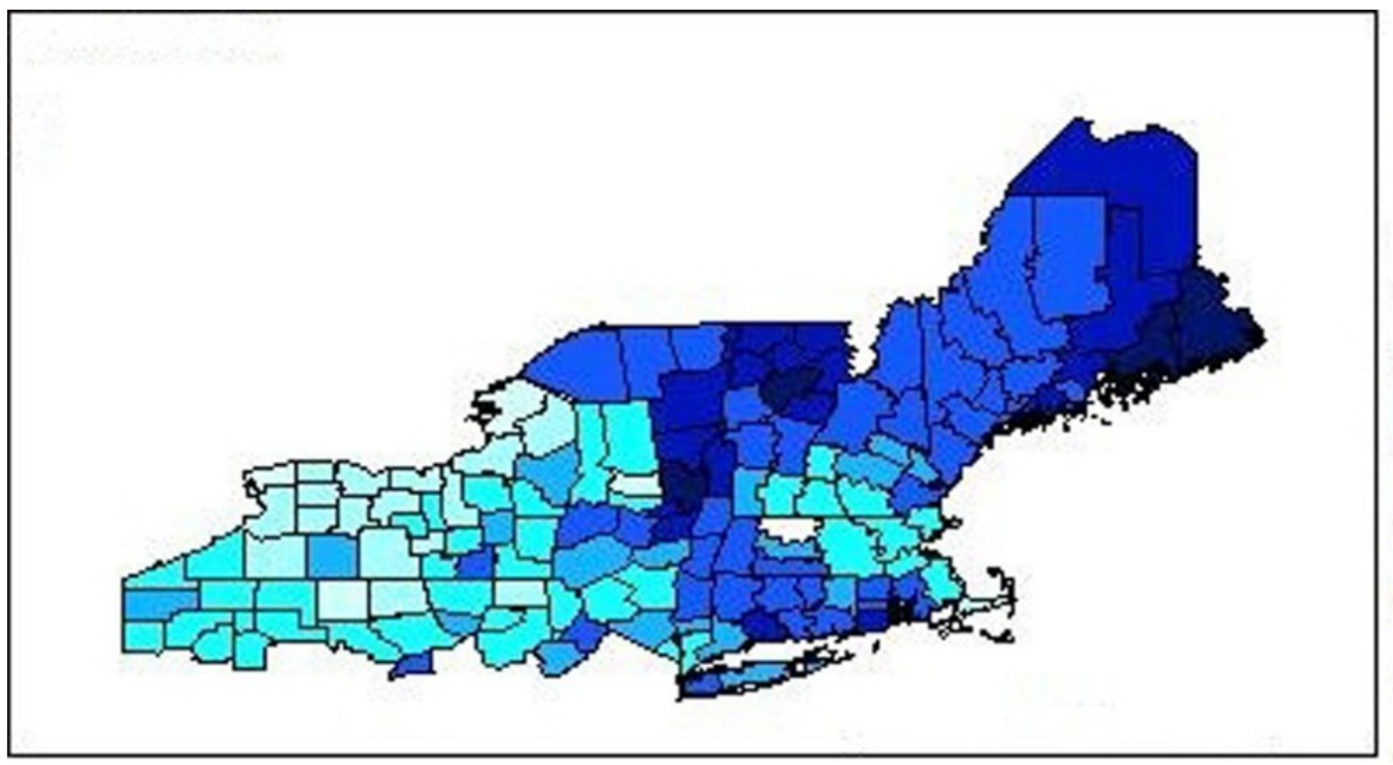

County Means

$\square$ less than 10.0

-10.0 to -7.5

-7.5 to -2.5

-2.5 to 0.0

0.0 to 7.5

7.5 to 15.0

over 15.0 
Map 11. Random spatial effects from Model of Wealth Per Capita

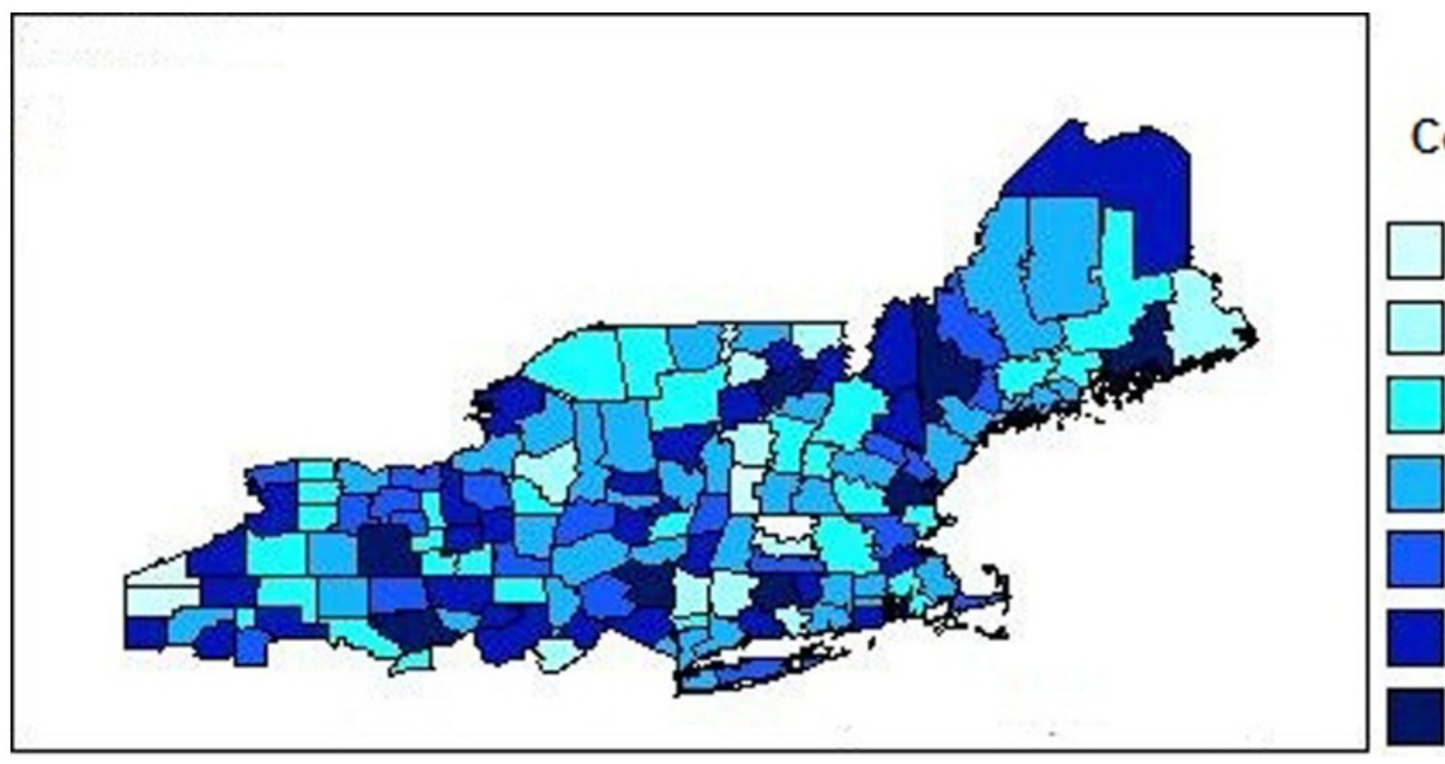

County Means

less than -75.0

-75.0 to -50.0

-50.0 to -25.0

-25.0 to 0.0

0.0 to 25.0

25.0 to 75.0

over 75.0

Map 12. Correlated Spatial Effects from model of wealth per capita

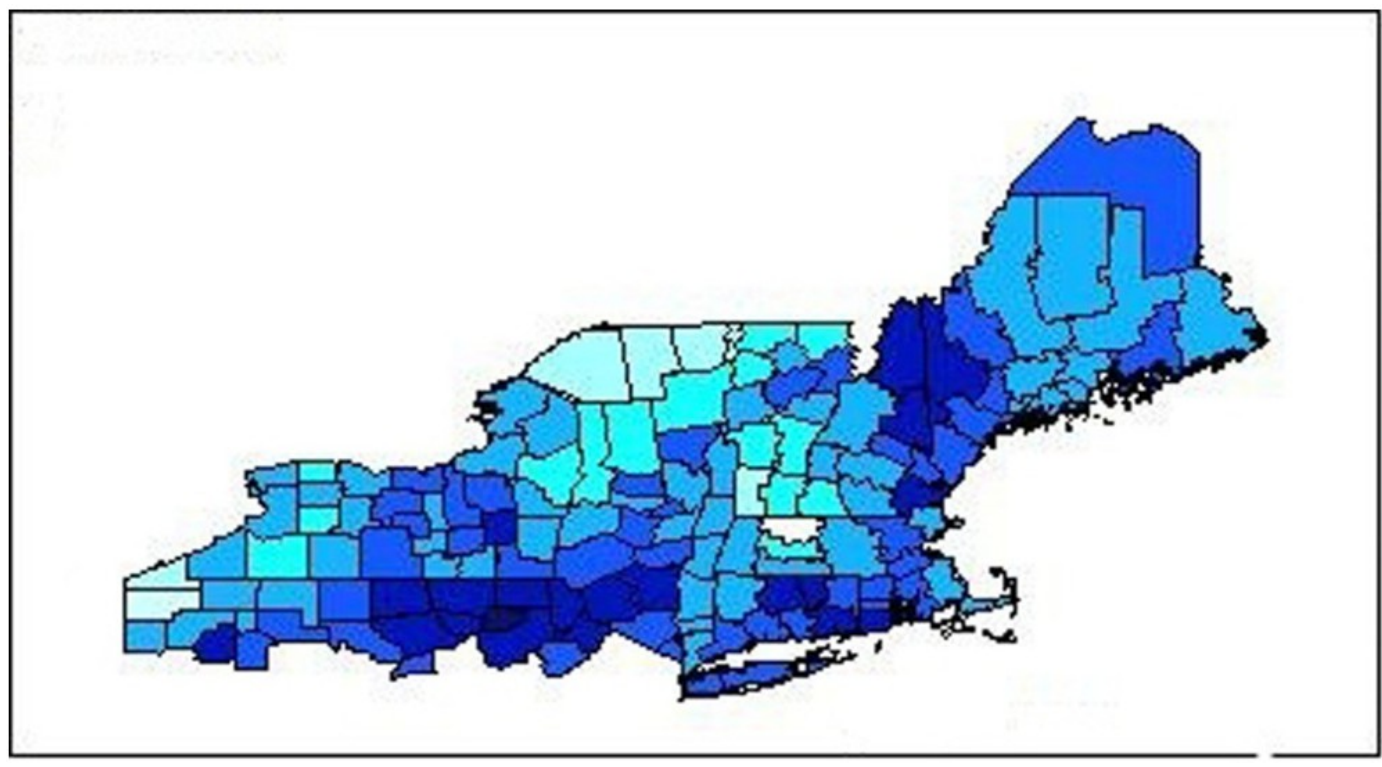

\section{County Means}

less than -75.0

-75.0 to -50.0

-50.0 to -25.0

-25.0 to 0.0

0.0 to 25.0

25.0 to 75.0

over 75.0 
Map 13: Economic Zones

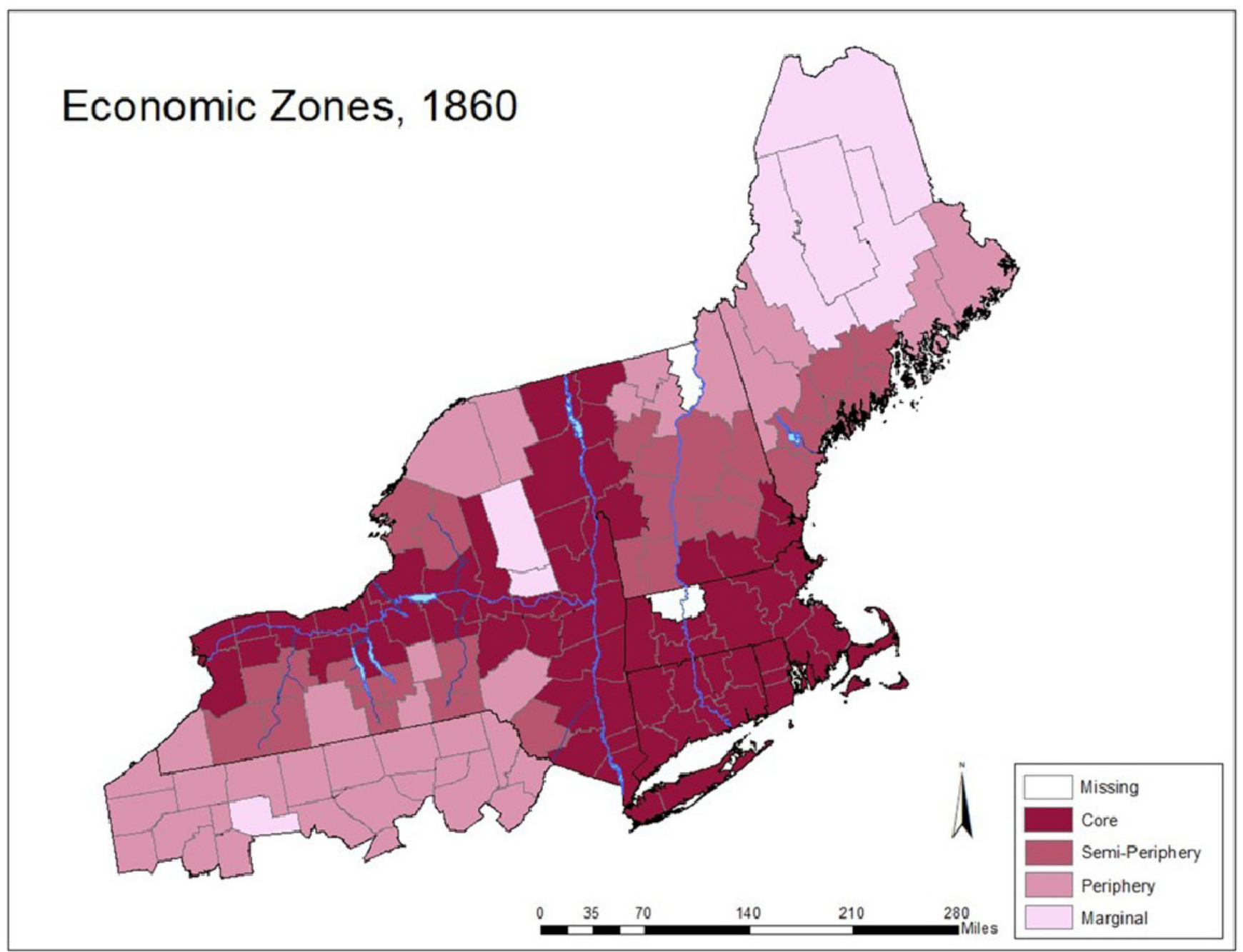


Map 14. Soils by township in Genesee County, NY

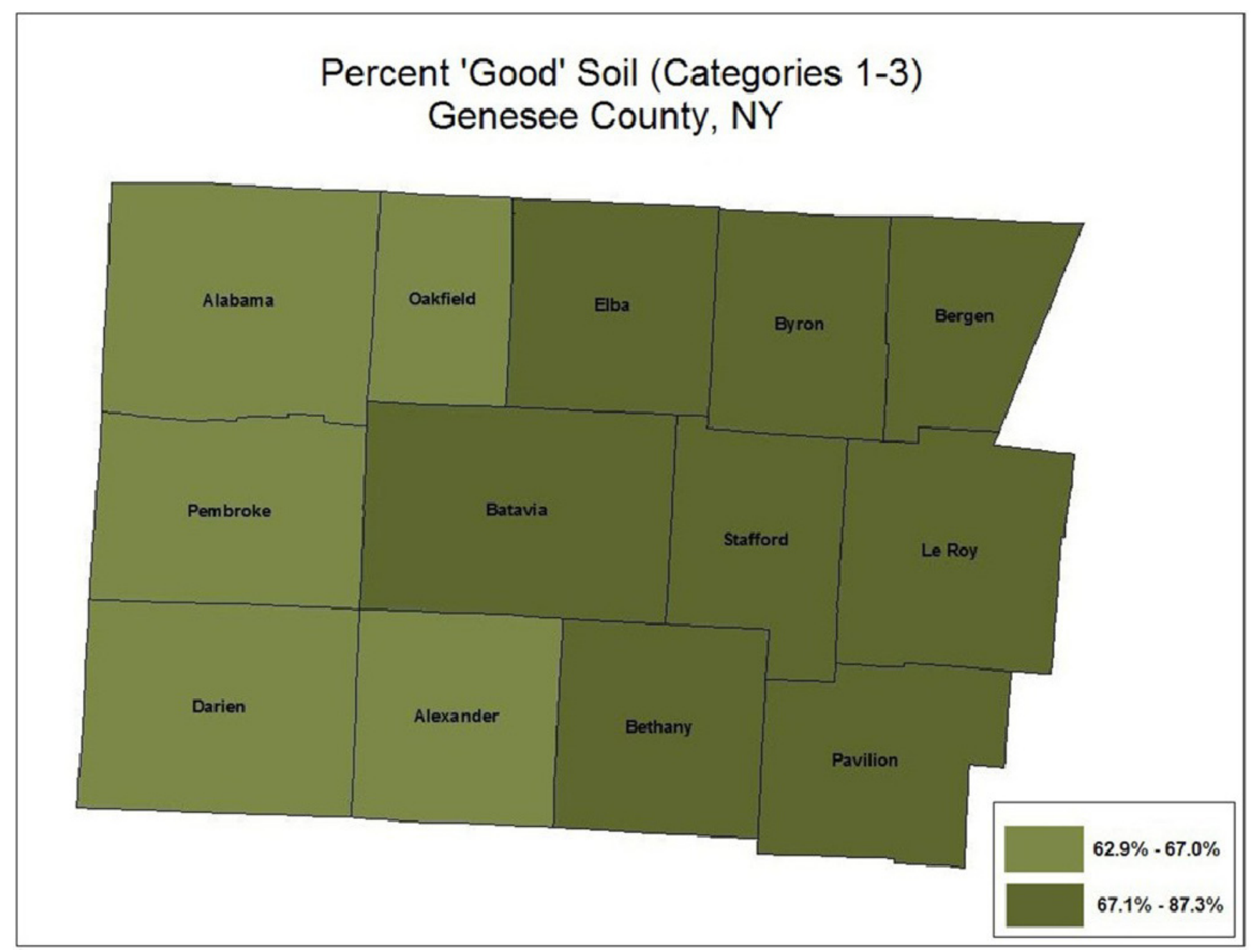


Map 15. Soils by township in Hillsborough County, NH

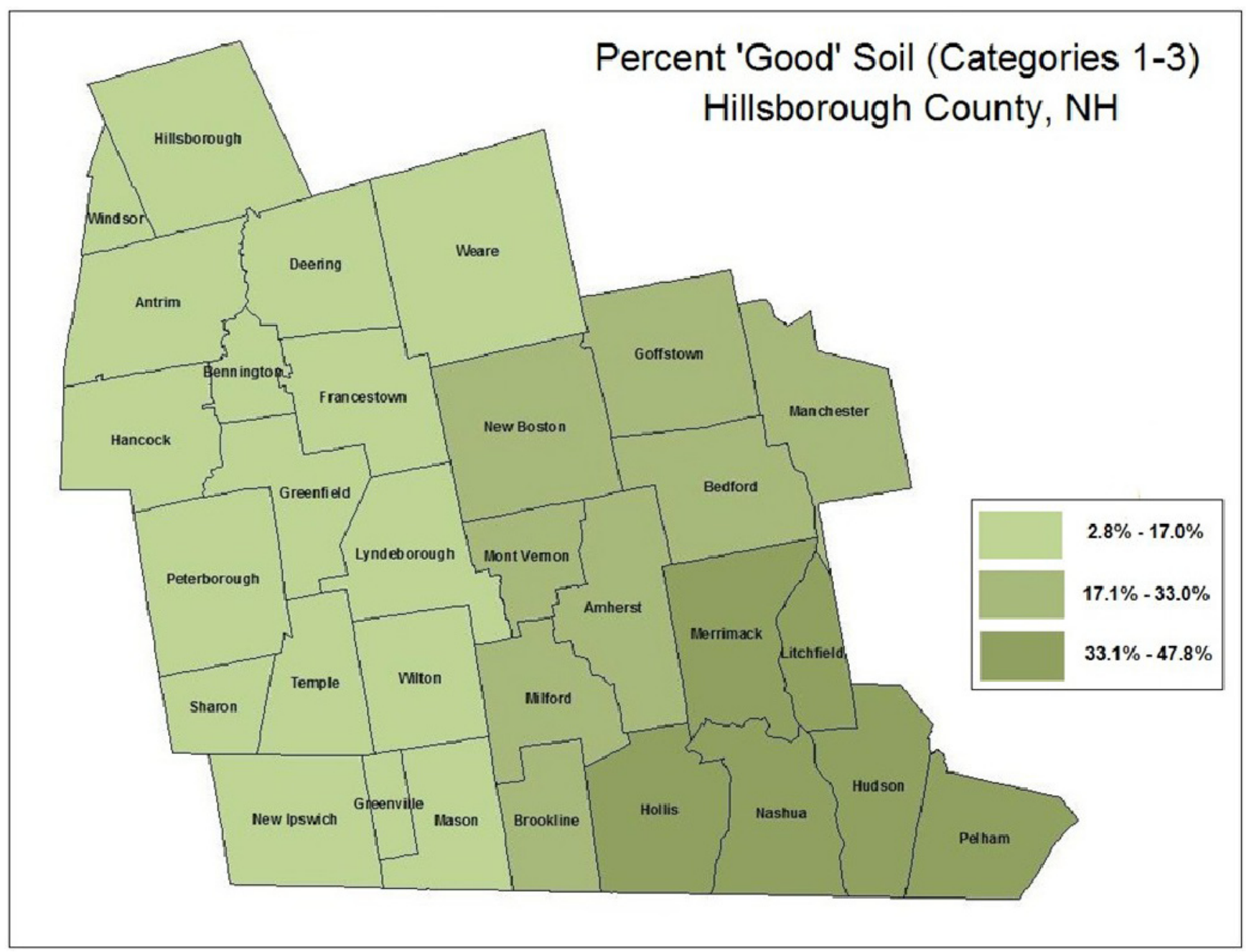

